\title{
Post-depositional redistribution of trace metals in reservoir sediments of a mining/smelting-impacted watershed (the Lot River, SW France)
}

\author{
Stéphane Audry ${ }^{\underline{a}, \underline{b}}, \underline{c}$, Cécile Grosbois ${ }^{\underline{b}, \underline{d}}$, Hubert Bril ${ }^{\underline{b}}$, Jörg Schäfer ${ }^{\underline{a}}$, Jakub Kierczak ${ }^{\mathbf{b}}, \underline{\underline{e}}$ \\ and Gérard Blanc ${ }^{\mathbf{a}}$
}

${ }^{\text {a } U n i v e r s i t e ́ ~ d e ~ B o r d e a u x, ~ U M R ~} 5805$ EPOC, Avenue des facultés, 33405 Talence cedex, France

${ }^{\mathrm{b}}$ Université de Limoges, Groupement de Recherche Eau Sol Environnement, IFR 145 GEIST, FST, 123 Avenue, A. Thomas, 87060 Limoges cedex, France

${ }^{\mathrm{c}}$ Université de Toulouse, UPS (OMP), LMTG, 14 Av., Edouard Belin, F-31400 Toulouse, France

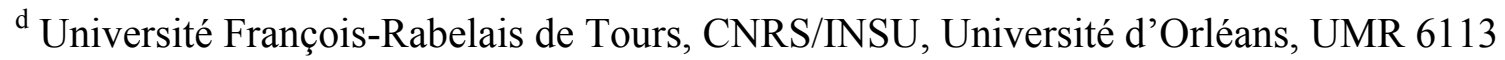
ISTO, FST, Parc Grandmont, F-37200 Tours, France

${ }^{\mathrm{e}}$ University of Wrocław, Institute of Geological Sciences, Cybulskiego 30, 50-205 Wrocław, Poland

\begin{abstract}
Mining/smelting wastes and reservoir sediment cores from the Lot River watershed were studied using mineralogical (XRD, SEM-EDS, EMPA) and geochemical (redox dynamics, selective extractions) approaches to characterize the main carrier phases of trace metals. These two approaches permitted determining the role of post-depositional redistribution processes in sediments and their effects on the fate and mobility of trace metals. The mining/smelting wastes showed heterogeneous mineral compositions with highly variable contents of trace metals. The main trace metal-bearing phases include spinels affected by secondary processes, silicates and sulfates. The results indicate a clear change in the chemical partitioning of trace metals between the reservoir sediments upstream and downstream of the mining/smelting activities, with the downstream sediments showing a 2-fold to 5-fold greater contribution of the oxidizable fraction. This increase was ascribed to stronger postdepositional redistribution of trace metals related to intense early diagenetic processes, including dissolution of trace metal-bearing phases and precipitation of authigenic sulfide phases through organic matter (OM) mineralization. This redistribution is due to high inputs (derived from mining/smelting waste weathering) at the water-sediment interface of (i) dissolved $\mathrm{SO}_{4}$ promoting more efficient $\mathrm{OM}$ mineralization, and (ii) highly reactive trace metal-bearing particles. As a result, the main trace metal-bearing phases in the downstream sediments are represented by $\mathrm{Zn}$ - and Fe-sulfides, with minor occurrence of detrital zincian spinels, sulfates and Fe-oxyhydroxides. Sequestration of trace metals in sulfides at depth in reservoir sediments does not represent long term sequestration owing to possible resuspension of anoxic sediments by natural (floods) and/or anthropogenic (dredging, dam flush) events that might promote trace metal mobilization through sulfide oxidation. It is estimated that, during a major flood event, about $870 \mathrm{t}$ of $\mathrm{Zn}, 18 \mathrm{t}$ of $\mathrm{Cd}, 25 \mathrm{t}$ of $\mathrm{Pb}$ and $17 \mathrm{t}$ of $\mathrm{Cu}$ could be mobilized from the downstream reservoir sediments along the Lot River by resuspensioninduced oxidation of sulfide phases. These amounts are equivalent to 13 -fold $(\mathrm{Cd}), \sim 6$-fold
\end{abstract}


$(\mathrm{Zn})$, 4-fold $(\mathrm{Pb})$ the mean annual inputs of the respective dissolved trace metals into the Gironde estuary.

\section{Introduction}

Large quantities of tailings and wastes still containing high concentrations of trace metals are produced by mining and smelting activities. Mobilization of trace metals from these tailings and wastes due to complex biological, geochemical and physical processes, including oxidation of sulfide minerals ([McGregor et al., 1998], [Audry et al., 2005] and [Moncur et al., 2005]), weathering of secondary phases ([Gieré et al., 2003] and [Hammarstrom et al., 2005]) and erosion, induces serious environmental threats. Once trace metals have been released into waterways, they can disperse over hundreds of kilometers in both particulate and dissolved forms ([Salomons, 1995] and [Schäfer et al., 2002]) thus contaminating soils, sediments and biota far from their primary source. Therefore, characterization of the mobility, accumulation and transformation of trace metals along the river course is necessary to understand the fate of trace metals in hydrosystems impacted by weathering of mining and smelting wastes.

While there are numerous examples of works dealing with mining/smelting wastes (e.g. [Blowes et al., 1998], [Sidenko et al., 2001], [Courtin-Nomade et al., 2003] and [Romero et al., 2007]) or downstream polluted fluvial sediments (e.g. [Hudson-Edwards et al., 1999], [Hudson-Edwards et al., 2005], [Morillo et al., 2002], [Galan et al., 2003] and [Grosbois et al., 2007]), there is a lack of knowledge on the fate of trace metals between these compartments. Additionally, most of the studies regarding polluted fluvial sediments are based on surface sediment samples precluding investigations on (i) temporal changes in trace metal inputs into the fluvial system, and (ii) post-depositional redistribution of trace metals related to early diagenesis processes. The study of the latter is pivotal as post-depositional redistribution processes can modify the trace metal-bearing phases ([Pedersen, 1985], [van den Berg et al., 1999] and [Audry et al., 2006a]) and can affect reactivity, mobility and bioavailability of trace metals, including various priority pollutants.

This study on the Lot River system (SW France), which is impacted by weathering of mine and smelting wastes, is based on a multi-compartment sampling strategy (mining/smelting waste samples and downstream reservoir sediment cores), and a multi-parameter approach. The latter combines (i) mineralogical characterization using XRD, SEM-EDS and EMPA, (ii) chemical partitioning that is widely applied in the mining/smelting waste environment (e.g. [Dold and Fontbote, 2002], [Bird et al., 2003] and [Galan et al., 2003]), and (iii) characterization of redox conditions in sediment cores through pore water concentration-depth profiles of the major reactive species. The aim of the study is to document the behavior of trace metal-bearing phases within the key compartments of the studied system, and to improve the understanding of the role of post-depositional redistribution processes in fluvial sediments and their effect on the fate and mobility of trace metals.

\section{Study area and sampling sites}

The Lot River watershed (11,840 km²; Fig. 1), tributary of the Garonne River, is divided into three main geological zones: (i) igneous (basalts and granites) and metamorphic (micaschists and gneisses) rocks in the upstream watershed; (ii) Jurassic calcareous sedimentary rocks in the median watershed; (iii) Tertiary and Quaternary alluvium deposits in the downstream watershed. The Lot River is impacted by polymetallic pollution resulting from mining/smelting activities since the late nineteenth century ([Blanc et al., 1999], [Grousset et 
al., 1999], [Schäfer et al., 2002], [Schäfer et al., 2006] and [Audry et al., 2004a]). The main point source of trace metals was identified in the upper part of the Lot River (Boutier, 1981), where a small tributary (the Riou Mort River; Fig. 1) drains areas of waste from an abandoned $\mathrm{Zn}$-ore manufacturing facility. The facility had been active from 1842 to 1987, the smelting activity was ended following an accidental trace metal pollution incident in 1986. Zinc was produced from smithsonite $\left[\mathrm{ZnCO}_{3}\right]$ dominated ores until 1922 by thermic reduction and then from sphalerite $[\mathrm{ZnS}]$ dominated ores by electrolysis. About $35 \mathrm{Mt}$ (unpublished data) of process waste still rich in $\mathrm{Zn}\left(10,000-20,000 \mathrm{mg} \mathrm{kg}^{-1}\right)$ and $\mathrm{Cd}\left(\sim 200-400 \mathrm{mg} \mathrm{kg}^{-1}\right)$ were deposited in 3 main areas (W-I, W-II and W-III) in the Riou Mort watershed (Fig. 1).

Remediation work was undertaken on the $\mathrm{W}-\mathrm{I}$ area, which is composed of three storage basins, by collecting and treating the drainage water in order to reduce direct trace metal release into the river system. In contrast, $\mathrm{W}-\mathrm{II}$ and $\mathrm{W}-\mathrm{III}$ are still exposed to rain water and thus are eroded and leached.

The fluvial sediments investigated in this study were collected from three hydroelectric reservoirs along the Lot River (Fig. 1): (i) Marcenac, located upstream of the confluence with the Riou Mort River, in order to obtain representative background values and mineralogical partitioning of trace metals in the upper Lot River watershed; (ii) Cajarc $\left(0.3 \mathrm{~km}^{2}\right.$; established in 1950), the first reservoir, located $25 \mathrm{~km}$ downstream of the confluence with the Riou Mort River; (iii) Temple (3.8 $\mathrm{km}^{2}$; established in 1951), upstream of the confluence of the Lot and Garonne Rivers and representative of the outlet of the Lot River watershed.

\section{Methodology}

\subsection{Sampling}

In 2001, three continuous $\sim 1 \mathrm{~m}$-long sediment cores were collected from the three different reservoir lakes (Marcenac, Cajarc and Temple) in locations corresponding to the former river channels. The reservoir sediments were collected using an interface corer consisting of a $10 \times 10 \mathrm{~cm}$ rectangular Plexiglas tube. This device permits sampling of the uppermost decimeters of the sediments, the undisturbed water-sediment interface and the overlying bottom water. Concentration-depth profiles of dissolved $\mathrm{O}_{2}$ in bottom and pore waters were obtained immediately after core recovery using a cathode-type mini-electrode ([Revsbech and Jørgensen, 1984] and [Chaillou et al., 2002]). The temperature was maintained constant with an insulating device. This operation was completed within 15 min of core recovery. The overlying bottom waters were then collected from the Plexiglas tube using a $10 \mathrm{~mL}$ syringe, filtered through driven filter unit $\left(0.22 \mu \mathrm{m}\right.$ porosity; Sartorius $\left.{ }^{\circledR}\right)$ and divided into three aliquots for nutrient, $\mathrm{SO}_{4}^{2-}$ and metal analyses. Aliquots for nutrient analyses were stored at $-20{ }^{\circ} \mathrm{C}$ until analysis; aliquots for $\mathrm{SO}_{4}^{2-}$ analysis were stored at $4{ }^{\circ} \mathrm{C}$; aliquots for metal measurements were acidified ( $\mathrm{pH} 1 ; \mathrm{HNO}_{3}$ ultrapure 1\%o) and stored in acid-cleaned tubes at $4{ }^{\circ} \mathrm{C}$. Subsequently, the cores were sliced in thin horizontal sections with a plastic cutter at a $0.5 \mathrm{~cm}$ resolution from the surface to $5 \mathrm{~cm}$ in the lower part of the cores. All the samples were collected in acid-cleaned and $\mathrm{N}_{2}$-flushed centrifuge vials and centrifuged at $5000 \mathrm{rpm}$ for $20 \mathrm{~min}$. For each sample, the supernatant (i.e. pore water) was processed and stored as for bottom water samples. The sediment samples were then sealed in double sampling-bags. In the laboratory, sediment samples were dried at $50{ }^{\circ} \mathrm{C}$ to constant weight and then powdered and homogenized with a manual agate mortar. Surface samples from the three smelting-waste sites (W-I, W-II and W-III) in the Riou Mort watershed were collected by hand. In the absence of detailed knowledge regarding the spatial heterogeneity of each waste site, one 
representative sample of the main observable waste type from each site was collected. These waste samples were selected to give information on the main mineralogical phases from which trace metals could be derived rather than to give exhaustive information on the mineralogical complexity of the waste areas. The waste samples were disaggregated and homogenized with an agate mortar.

\subsection{Mineralogical characterization of the solid material}

The mineralogy of samples was characterized on unoriented sample powder by X-ray diffraction (XRD) using $\mathrm{Cu} \mathrm{K} \alpha$ radiation. Diffractograms were recorded from $3^{\circ}$ to $70^{\circ} 2 \theta$ with steps of $0.02^{\circ}$ and counting time of $15 \mathrm{~s} / \mathrm{step}$ using a Siemens D5000 diffractometer. Polished thin sections of embedded powdered material in epoxy resin were observed with a Philips XL-30 scanning electron microscope (SEM) using an accelerating voltage of $20 \mathrm{kV}$ equipped with an X-ray energy-dispersive spectral analyser (EDS). Selected solid phases were analysed quantitatively using a CAMECA-SX50 electron microprobe. For major oxides, the microprobe operated at $15 \mathrm{kV}$ with a beam current of $4 \mathrm{nA}$ and a counting time of $10 \mathrm{~s}$. The analysed interaction volume (modeled as a pear-shape) is typically about $1-2 \mu \mathrm{m}^{3}$ under these operating conditions which may correspond to a larger volume than the target particle, usually very fine, small and presenting a heterogeneous chemical composition. However, several analysis spots were carried out on each particle each time it was possible. The determination of trace element composition below $0.2 \mathrm{wt}$.\% was obtained with a voltage of $35 \mathrm{kV}$, and a beam current of $500 \mathrm{nA}$ using the procedure described in Fialin et al. (1999). Hence, for these trace element concentrations, a single set of analytical data corresponds to data from 10 spots for a $10 \mathrm{~s}$ period for each (Fialin et al., 1999) in order to reduce sample damage due to prolonged irradiation and to decrease detection limits. Detection limits for these trace elements are several hundred $\mathrm{mg} \mathrm{kg}^{-1}$.

Finally, mineralogical compositions were determined from chemical compositions using the mineral list of the international mineralogical association for the sake of clarity. However, it should be noted that anthropogenic phases are not minerals as defined by Nickel (1995).

Amounts of $\mathrm{Fe}^{2+}$ and $\mathrm{Fe}^{3+}$ in spinel-group minerals were calculated by charge-balance: it was considered that all the $\mathrm{Zn}^{2+}$ cations are allocated to the tetrahedral sites whereas all the $\mathrm{Al}^{3+}$ cations occupy octahedral sites. Then $\mathrm{Fe}^{2+}$ and $\mathrm{Fe}^{3+}$ were calculated according to the formula $\mathrm{Fe}^{3+}=$ total $\mathrm{Fe} \times 2 / 3 ; \mathrm{Fe}^{2+}=$ total $\mathrm{Fe} \times 1 / 3 \mathrm{Fe}^{3+}$, preferably occupying tetrahedral sites, $\mathrm{Fe}^{2+}$ (and $\mathrm{Mg}^{2+}$ ) being shared between the remaining vacant sites.

\subsection{Selective extraction procedures}

The selective single extraction procedures used in the present study (i.e. using a separate aliquot of the same sample for each reagent) are principally based on the sequential extraction scheme according to Tessier et al. (1979). (Tack et al., 1996) and (Tack et al., 1999) showed that similar results for trace metal partitioning $(\mathrm{Cu}, \mathrm{Cr}, \mathrm{Ni}, \mathrm{Pb}$ and $\mathrm{Zn})$ in sediments were obtained from the conventional Tessier et al. (1979) sequential extraction method and from single extractions using identical operating conditions applied in each individual extraction (Table 1). In this study, three different operationally-defined fractions were targeted, according to Audry et al. (2006b): (i) fraction F1 represents the trace metals loosely bound to particulates (i.e. exchangeable) and/or associated with carbonates; (ii) fraction F2 represents trace metals associated with reactive Fe- and Mn-oxides; and (iii) fraction F3 represents trace metals associated with OM and 'reactive' sulfides (i.e. excluding pyrite). The total metal content (TMC) of the solid samples was determined using the digestion method detailed in 
Schäfer et al. (2002): Representative sub-samples (e.g. $30 \mathrm{mg}$ of dry, powdered and homogenized material) were digested in closed Teflon reactors (Savillex ${ }^{\circledR}$ ) on a heating plate $\left(2 \mathrm{~h}\right.$ at $\left.110^{\circ} \mathrm{C}\right)$ using $750 \mathrm{~mL} \mathrm{HCl}(12 \mathrm{~N}$, suprapur), $2 \mathrm{~mL} \mathrm{HF} \mathrm{(26} \mathrm{N,} \mathrm{suprapur)} \mathrm{and} 250 \mathrm{~mL}$ $\mathrm{HNO}_{3}(14 \mathrm{~N}$, suprapur). After evaporation to dryness, the residues were completely redissolved in $150 \mathrm{~mL} \mathrm{HNO}_{3}(14 \mathrm{~N})$ on a heating plate and after cooling diluted to $10 \mathrm{~mL}$ in a volumetric flask using Milli-Q ${ }^{\circledR}$ water. The residual fraction (RF) was estimated as the difference between the TMC and the sum of the fractions F1 + F2 + F3. The contribution of each operationally-defined fraction in a sample is expressed as a percentage of the TMC.

\subsection{Analytical methods}

Nitrate in bottom and pore waters was measured by flow injection analysis (FIA) according to Anderson (1979). Ammonia was determined with the FIA method described by Hall and Aller (1992). Sulfate concentrations were determined by ion chromatography (Dionex DX-120) using the AFNOR (1996) method. Dissolved Fe and Mn concentrations were measured using double-beam Flame-AAS (Perkin-Elmer 420). The precision estimated from replicate measurements of the same sample $(n=10)$ was $\pm 3 \%$ for Mn and $\pm 7 \%$ for Fe. Accuracy estimated from parallel analyses of the international certified reference water (SLRS-4) was better than $10 \%$.

Particulate organic C (POC) and total S (Stot) were measured in the sediment samples directly from the dry, powdered and homogenized material using a carbon/sulfur analyser (LECO, CS-125) according to Cauwet et al. (1990). Quality control was performed by measuring certified reference materials (LECO 501-503). The accuracy of all analyses was within 5\% of the certified values and precision was better than 5\% r.s.d. Cesium-137dating was performed on the sediment core from Cajarc (see Audry et al., 2004b). Iron and Mn concentrations in the sediments from total and selective extractions were determined using double-beam FlameAAS (see above).

Total major element concentrations in sediment and waste samples were determined by fusing $100 \mathrm{mg}$ of powdered sample with $750 \mathrm{mg}$ of Li tetraborate in a glassy graphite melting pot at $1000{ }^{\circ} \mathrm{C}$ followed by dissolution in a glycerin- $\mathrm{HCl}$ solvent (Samuel et al., 1985) and analysis by ICP-AES. Accuracy, determined by analysis of certified international reference sediment (1646A-NISC), was within $5 \%$ of the certified values (at the $2 \sigma$ level).

Trace metal concentrations in bottom and pore waters, in sediments (total and selective extractions) and wastes were determined using ICP-MS (Elan 5000, Perkin-Elmer). The analytical methods employed were quality checked by analysis of certified international reference waters (SLRS-3, SLRS-4). Accuracy was within 5\% of the certified values and the analytical error (relative standard deviation) generally better than $5 \%$ for concentrations 10 times higher than detection limits.

\section{Results and discussion}

\subsection{Characteristics of metal-bearing phases in the smelting area}

\subsubsection{Bulk composition and mineralogy}

As in other former industrial areas (e.g. Thiry et al., 2002), trace metal concentrations in the waste area samples (W-I, W-II and W-III; Fig. 1) are high (Table 2), especially for Pb (0.3- 
$0.9 \%)$ and $\mathrm{Zn}(1.7-2.1 \%)$. The main mineralogical assemblage is characterized by spinelgroup minerals (franklinite and magnetite), sulfates (barite, gypsum, anglesite and jarosite), willemite and phyllosilicates (Fig. 2). They can be either primary phases such as residues of smelting processes or authigenic, formed by precipitation from trace metal-rich waters. Relict ore minerals such as sphalerite, zincite and pyrite were also identified by SEM observations. They were not identified in XRD patterns, due to their low abundance $(<5 \%)$ and their trace metal content could not be determined by EMPA because of their small size $(<10 \mu \mathrm{m})$.

\subsubsection{Main metal-bearing phases}

\subsubsection{Spinels}

Spinels, commonly found in smelting wastes ([Kucha et al., 1996], [Parsons et al., 2001] and [Piatak et al., 2004]), generally originate from sphalerite transformation during the roasting step in $\mathrm{Zn}$ pyrometallurgical processes. In the studied smelting area, zincian spinels were identified only in W-I (Fig. 1), where they constitute an abundant Zn-bearing phase. Zincian spinels form large grains, up to $50 \mu \mathrm{m}$, and they do not show obvious alteration (Fig. 3A). Their $\mathrm{ZnO}$ concentrations range from $20.9 \mathrm{wt} . \%$ to $50.1 \mathrm{wt} \%$ corresponding to a wide range of composition from franklinite-type $\left(7 \mathrm{nFo}_{2} \mathrm{tt}_{\mathbf{3}} \mathrm{O}_{4}\right.$, Table 3$)$ to zincian aluminous spinels with compositions close to $(\mathrm{Zn}, \mathrm{Fe})_{2}(\mathrm{Al}, \mathrm{Fe})_{2} \mathrm{O}_{8}$. Similar compositions were reported for $\mathrm{Zn}-\mathrm{Pb}$ slags from Świętochłowice (Poland; Puziewicz et al., 2007) and for $\mathrm{Cu}$ slag from the Penn Mine, USA (Parsons et al., 2001). In situ trace metal content, in these spinels, is very variable, ranging from 0.19 to $0.74 \mathrm{wt} . \% \mathrm{PbO}$, from 0.18 to $0.68 \mathrm{wt} . \% \mathrm{CuO}$ and from 0.10 to 0.39 wt. $\% \mathrm{CdO}$. These ranges are of the same order of magnitude as those in zincian spinels observed in the downstream reservoir sediments (see below) but are 5-fold $(\mathrm{Zn}), 9$-fold $(\mathrm{Pb})$ and 4-fold $(\mathrm{Cd})$ higher than concentrations reported for spinels from Świętochłowice and Penn Mine slags.

\subsubsection{Silicates}

Willemite $\left[\mathrm{Zn}_{2} \mathrm{SiO}_{4}\right]$ is a primary phase currently observed in $\mathrm{Zn}$-smelting environments ([Parsons et al., 2001], [Sidenko et al., 2001] and [Claassen et al., 2002]) and mostly originates from smelting processes (Isaure et al., 2002). In the studied site, willemite was observed in the smelting waste $\mathrm{W}-\mathrm{I}$ by XRD (Fig. 2). At a microscopic scale, hemimorphite $\left[\mathrm{Zn}_{4} \mathrm{Si}_{2} \mathrm{O}_{7}(\mathrm{OH})_{2} \cdot\left(\mathrm{H}_{2} \mathrm{O}\right)\right]$ was mostly observed (Fig. 3B). Hemimorphite usually derives from willemite alteration, growing on willemite edges in highly hydrated environments (Hitzman et al., 2003; Courtin-Nomade, personnal communication). The observed hemimorphite have $\mathrm{ZnO}$ concentrations ranging from 53.2 to $59.4 \mathrm{wt} . \%$ and $\mathrm{FeO}$ concentrations ranging from 5.2 to $11.7 \mathrm{wt} . \%$ in the unaltered zones (Table 3). These $\mathrm{FeO}$ and $\mathrm{ZnO}$ concentrations likely reflect solid-solution variations of primary willemite (e.g. Jak et al., 2002). Associated $\mathrm{SiO}_{2}$ concentrations vary from 16.8 to $22.8 \mathrm{wt} . \%$. Trace metal concentrations are very variable (up to $1.4 \mathrm{wt} . \% \mathrm{CdO}, 1.5 \mathrm{wt} \% \mathrm{CuO}$ and $0.43 \mathrm{wt} . \% \mathrm{PbO}$ ) showing no apparent trend with major oxides and/or alteration state.

\subsubsection{Sulfates}

Sulfates and oxyhydroxysulfates are commonly encountered as authigenic phases in mining and smelting wastes ([Gieré et al., 2003] and [Sidenko and Sherriff, 2005]), where they principally form during the oxidation of sulfide minerals (Jambor, 1994). 
Iron-oxyhydroxysulfates, jarosite, were observed in W-I and W-II (Fig. 2). Their Fe/S atomic ratios range from 3.6 to 20.8 which is high compared to $\mathrm{Fe} / \mathrm{S}$ ratios of hydroxysulfates generally observed in smelting-impacted environments (e.g. jarosite $\mathrm{XFe}_{3}\left(\mathrm{SO}_{4}\right)_{2}(\mathrm{OH})_{6}$; [Graupner et al., 2007] and [Romero et al., 2007]). Their overall trace metal contents are comparable to Fe-rich precipitates produced during Fe removal and purification stages used in Zn hydrometallurgy (Loan et al., 2006). This suggests that these Fe-oxyhydroxysulfates could either derive from material directly dumped in the smelting wastes or formed within the wastes by in-situ oxidation of sulfide minerals under acidic conditions.

Other identified sulfates, common in the three waste areas, are anglesite, barite, anglesitebarite solid solutions and gypsum (Fig. 2). In the study context, much of the anglesite originated from leaching operations during Zn hydrometallurgical processes where it constitutes one of the end-products of the strong-acid leaching stage (Buban et al., 1999). Additionally, minor amounts of anglesite may have formed as a secondary phase by alteration of primary relict galena (Antunes et al., 2002). Maximum $\mathrm{Cu}$ and $\mathrm{Cd}$ concentrations ( $0.45 \mathrm{wt} . \% \mathrm{CuO}$ and $0.11 \mathrm{wt} . \% \mathrm{CdO}$, respectively) are found in barite. These concentrations are higher than those found in anglesite. However, the observed barite is characterized by lower $\mathrm{Zn}$ concentrations ( $0.69 \mathrm{wt} . \% \mathrm{ZnO}$ ) compared to anglesite. Anglesite-barite solid solutions, also described by Lee et al. (2005), were frequently observed as isolated grains or associated with aluminosilcate aggregates (Fig. $3 \mathrm{C}$ ). Atomic $\mathrm{Ba} / \mathrm{Pb}$ ratios are highly variable, even at the grain scale, ranging from 0.11 to 0.65 with a higher occurrence for the $\mathrm{Pb}$-rich compositions than for the Ba-rich ones. The $\mathrm{PbO}$ concentrations range from $34.6 \mathrm{wt} \% \%$ to 60.5 wt.\% (Table 3). Associated trace metals in these solid solutions are mainly $\mathrm{Cr}$ and $\mathrm{Zn}$. Finally, gypsum, a common phase in oxidized smelting and mining waste submitted to atmospheric conditions ([Jambor, 1994], [Roussel et al., 1999], [McGregor and Blowes, 2002] and [Ettler et al., 2003]), is ubiquitous in the dump material as small $(<20 \mu \mathrm{m})$, isolated but frequent crystals in W-I, and occurring as a cement in W-II and W-III. Similarly to what has been observed from chemical extraction studies ([Ribet et al., 1995] and [Widerlund et al., 2005]) or from mineral analyses (Lottermoser and Cairns, 2005) of mining residues from other sites, $\mathrm{Zn}, \mathrm{Pb}, \mathrm{Cu}$ and $\mathrm{Cd}$ were not detected in gypsum in the present study.

\subsection{Characteristics of metal-bearing phases in the reservoir sediments}

\subsubsection{Bulk composition and mineralogy of the sediments}

The three cores consist of dark and unconsolidated sediment with grain sizes ranging from

fine-sand to clay. The clay-silt fraction $(<63 \mu \mathrm{m})$ represented from $\sim 50 \%$ (Marcenac) to $75 \%$ (Cajarc and Temple) of the whole sediment, with the fine-silt fraction accounting for $25 \%$ (Audry et al., 2004b). The major element composition in the three cores (Table 4) is dominated by $\mathrm{SiO}_{2}$ (57-64 wt.\%), $\mathrm{Al}_{2} \mathrm{O}_{3}\left(12-15\right.$ wt.\%) and $\mathrm{Fe}_{2} \mathrm{O}_{3}$ (4-6 wt.\%). The mean $\mathrm{CaO}$ content in the sediment at the Temple site (i.e. $\sim 4 \mathrm{wt} . \%$ ) is clearly higher than that of the two other sites (1.4-1.8 wt.\%), which was probably due to drainage of lacustrine-fluvial deposits of limestone and molasse in the most downstream part of the Lot River system (Semhi et al., 2000). The mean major element composition is consistent with the XRD results for the three reservoir sediment cores, with a main mineralogical assemblage of quartz, muscovite, chlorite and plagioclases. The distribution as a function of depth of $\mathrm{Fe}_{2} \mathrm{O}_{3}$ concentration (Fig. 4) in the sediments shows relatively flat profiles in the Marcenac and Cajarc sites while showing a slight down-core decrease for the Temple site. The distribution of $\mathrm{SiO}_{2}$ and $\mathrm{Al}_{2} \mathrm{O}_{3}$ (Fig. 4) in the three sediment cores shows mirrored profiles reflecting the presence of these two elements 
mainly in quartz and Al silicates. POC is variable in the three cores (Table 4), with mean concentrations of $4.2 \pm 2.0 \%$ (Marcenac), $5.2 \pm 1.9 \%$ (Cajarc) and $3.4 \pm 2.0 \%$ (Temple). Total $\mathrm{S}$ concentrations differ from one core to another (Table 4), with mean values of $0.08 \pm 0.03 \%$ (Marcenac), $0.33 \pm 0.11 \%$ (Cajarc) and $0.13 \pm 0.06 \%$ (Temple).

\subsubsection{Main metal-bearing phases}

Identification of trace metal-host minerals was only carried out for three different layers of the ${ }^{137} \mathrm{Cs}$-dated sediment core at Cajarc: (i) L1, at $5 \mathrm{~cm}$ depth (dated at 1999; Audry et al., 2004b), representative of the present time and reflecting remediation work (e.g. confinement of smelting waste areas) and recent erosion/alteration processes in the Riou Mort watershed; (ii) L2, at $42 \mathrm{~cm}$ depth (dated at 1986), corresponding to the accidental pollution peak; (iii) L3, at $80 \mathrm{~cm}$ depth (dated at 1970), representative of the chronic pollution when the $\mathrm{Zn}$-ore smelting facility was active in the Riou Mort watershed.

\subsubsection{Sulfides}

Inherited $\mathrm{Zn}$ - and Fe-sulfides are present in the reservoir sediment of Cajarc because they were processed as the dominant Zn-ore. Microscopy (SEM observations) and EMPA analyses suggest that they represent frequent trace metal-carriers in the three sediment layers. Zincsulfides are rather small $(\sim 10 \mu \mathrm{m})$ and consist mainly of sphalerite. They are accompanied by other phases of pyrometallurgical origin and belong to the $\mathrm{ZnS}-\mathrm{CdS}$ system recently described by Chaplygin et al. (2007) in a volcanic context. These phases have relatively high $\mathrm{Cd}(5.9-6.4$ wt.\%), $\mathrm{Cu}(0.1-2.3$ wt.\%) and $\mathrm{Pb}(0.05-1.3$ wt.\%) contents. Iron-sulfides, similar in size to sphalerite crystals, show compositions close to pyrrhotite [FeS] and pyrite or marcasite $\left[\mathrm{FeS}_{2}\right]$. Their trace metal content is highly variable and shows 30 -fold (Cd) and 4fold $(\mathrm{Pb})$ lower and 2-fold higher $(\mathrm{Cu})$ average concentrations compared to sphalerites.

\subsubsection{Sulfates}

Zinc-sulfates (zincosite-like, more or less hydrated) were observed in the sediment layer L2 impacted by the 1986 pollution. They are much less abundant than sulfides and oxyhydroxides. They are $\mathrm{Zn}$-rich with up to $52.3 \mathrm{wt} . \% \mathrm{ZnO}$ and also contain $\mathrm{PbO}$ (up to 0.7 wt.\%) and $\mathrm{CdO}$ (up to $0.2 \mathrm{wt} . \%$ ). As shown in Fig. 3D, hydrated forms could derive from $\mathrm{ZnS}$ alteration, they show $\mathrm{S}$ loss, a relative enrichment in $\mathrm{PbO}$ (7.8 wt.\%), in $\mathrm{CdO}$ (2.4 wt.\%) and a maximum release of $30 \%$ of $\mathrm{Zn}$, compared to the unaltered core.

\subsubsection{Zincian spinels}

Inherited zincian spinels were mainly observed in the deepest layer L3, i.e. they were deposited when the Zn-ore smelting facility was still active. They barely occur in the middle layer L2 and were not observed in the shallow layer L1. As in the smelting area, these spinels show a composition between franklinite and (Fe, Al)-spinels. Although the ability for spinel alteration is generally considered low ([Pooley, 2004] and [Soubrand-Colin et al., 2005]), EMPA low analytical totals (down to 76\%; Table 3) and morphology in SEM observations (Fig. 3E) indicate significant alteration features. In several grains, a loss of cohesion and a rim of a hydrated phase could be associated with a spinel-like core.

\subsubsection{Oxides and oxyhydroxides}


Iron oxyhydroxides are present in the three sediment layers. According to SEM observations, they show a wide range of size $(5-50 \mu \mathrm{m})$. As usual for this type of poor crystallinity phase, they are highly hydrated with EMPA analytical totals of lower than $75 \%$. They show variable trace metal contents, up to 4.1 wt. $\% \mathrm{ZnO}, 1.3$ wt. $\% \mathrm{As}_{2} \mathrm{O}_{3}, 0.9$ wt. $\% \mathrm{CdO}, 0.7$ wt. $\% \mathrm{CuO}$ and 0.6 wt. $\% \mathrm{PbO}$. Among them, spherical particles with diameters of $\sim 20 \mu \mathrm{m}$, having up to 87 wt.\% FeO (Table 3), were observed (Fig. 3F). These phases are similar to Fe-rich spheres observed in the magnetic fraction of fly ash produced by coal, ore and sulfide-burning plants ([Laperche and Bigham, 2002], [Kukier et al., 2003] and [Kierczak et al., 2009]). According to Hansen et al. (1981), such spherical particles could form during smelting by precipitation after oxidation of pyrite contained in the $\mathrm{Zn}$ mine ore and coal used for roasting. These spherical particles typically contain high amounts of $\mathrm{Cd}$ and $\mathrm{Zn}$ with high analytical totals (higher than 90\%; Table 3).

Processes of alteration and hydration partly control the fate of trace metals present in primary and secondary minerals by promoting their mobilization into the pore water of the reservoir sediments, diffusive transport and eventual release into the water column. However, trace metal mobilization can be limited by back-trapping processes in the sediment pile, such as (i) post-release (co-)precipitation with sulfide phases and/or (ii) adsorption on Fe-oxides, hydroxides, and/or clay minerals ([Spark et al., 1995] and [Battacharya and Gupta, 2008]). Accordingly, aluminosilicates with compositions close to clay minerals like kaolinite and containing significant trace metal concentrations (e.g. $1.4 \pm 0.1 \mathrm{wt} . \% \mathrm{ZnO}$ and $0.33 \pm 0.35$ wt. $\% \mathrm{PbO}$ ) were observed in the Cajarc sediments.

\subsection{Effects of early diagenesis processes on trace metal redistribution in reservoir sediments}

Additional to the alteration and hydration processes discussed above, redox processes accompanying OM mineralization, i.e. early diagenesis (Berner, 1980), are expected to control the fate of the metal-bearing phases present in the sediment pile. These processes are discussed in the following.

\subsubsection{Dissolved redox species profiles and associated processes}

The vertical distributions of major dissolved redox species show sharp concentration gradients near the water-sediment interface, indicating intense bacteria-mediated oxidation of OM ([Froelich et al., 1979] and [Postma and Jakobsen, 1996]) in the three reservoirs. The sediments feature anoxic conditions, as shown by the dissolved $\mathrm{O}_{2}$ concentrations below the detection limit just below the water-sediment interface (Fig. 5). Moreover, the bottom water of the reservoir is strongly (Cajarc, Temple) or totally (Marcenac) depleted in $\mathrm{O}_{2}$. Oxygen consumption is related to mineralization of OM proceeding in the bottom water. This result highlights the high oxidant demand of the reservoir sediments for OM mineralization. Nitrate drastically decreases below the water-sediment interface (Fig. 5), reflecting bacterial denitrification.

Sulfate concentrations in the bottom water are 3 times higher at Cajarc compared to the upstream of the Lot River (Fig. 5), which is due to the high inputs of $\mathrm{SO}_{4}^{2-}$ from the Riou Mort River into the Lot River (Audry et al., 2005). Similarly to $\mathrm{NO}_{3}^{-}, \mathrm{SO}_{4}^{2-}$ decreases sharply below the water-sediment interface (Fig. 5). The $\mathrm{SO}_{4}^{2-}$ decrease is mainly attributed to dissimilatory (bacteria-mediated) $\mathrm{SO}_{4}^{2-}$ reduction, which is supported by the associated $\mathrm{NH}_{3}$ 
production. While $\mathrm{CH}_{4}$ data are not available, $\mathrm{CH}_{4}$ production in the reservoir sediments was suggested by bubbles bursting out during the recovery of the sediment cores. Therefore, additional $\mathrm{SO}_{4}^{2-}$ consumption could be supported by anaerobic $\mathrm{CH}_{4}$ oxidation in the three reservoirs, as reported in marine environments characterized by high sedimentation rates and/or high POC contents ([Iversen and Jørgensen, 1985] and [Niewohner et al., 1998]). Slight enrichments of $\mathrm{SO}_{4}^{2-}$ (up to $13 \mu \mathrm{M}$ at Cajarc; Fig. 5) are observed at depth in the three cores. This excess of dissolved $\mathrm{SO}_{4}^{2-}$ is unlikely to be attributable to bacterial production of $\mathrm{SO}_{4}^{2-}$ from dissolved reduced sulfide coupled to $\mathrm{rO}_{3}^{-}$eduction (Suits and Arthur, 2000) as the observed excess of dissolved $\mathrm{SO}_{4}^{2-}$ occurs at a depth where the sediment is depleted. Therefore, this production of $\mathrm{SO}_{4}^{2-}$ is assigned to chemical reoxidation of dissolved sulfide by Fe- and Mn-oxides ([Aller and Rude, 1988] and [Böttcher and Thamdrup, 2001]).

Dissolved Mn profiles show broad peaks centered between 10 and $30 \mathrm{~cm}$ depth (depending on the core; Fig. 5). Dissolved Fe profile patterns are rather similar to those of Mn, while more scattered. The addition of dissolved $\mathrm{Mn}$ and $\mathrm{Fe}$ in anaerobic sediments is mainly attributed to both dissimilatory reduction (Lovley, 1997) and chemical reductive dissolution (by dissolved sulfide) of $\mathrm{Mn}$ - and Fe-oxides. At depth, dissolved $\mathrm{Mn}$ and $\mathrm{Fe}$ are partially removed from pore water. The removal of reduced $\mathrm{Fe}$ is probably due to authigenic precipitation of Fesulfides from dissolved sulfides produced by $\mathrm{SO}_{4}^{2-}$ reduction, which is in agreement with the presence of authigenic Fe-sulfides in the reservoir sediments as observed in Cajarc (not shown). Removal of reduced Mn cannot be attributed to co-precipitation with and/or adsorption on authigenic Fe-sulfides as these phases show Mn concentration below EMPA detection limit. The data rather suggest adsorption onto silicates that show relatively high $\mathrm{Mn}$ concentrations (ranging from $0.35 \mathrm{wt} . \%$ to $2.5 \mathrm{wt} . \% \mathrm{MnO}$ ). It is worth noting that the scatter of dissolved $\mathrm{Fe}$ and, to a lesser extent, Mn profiles suggests that diffusive steady state is not reached, which may reflect the high sedimentation rates in these reservoir environments ( $2.5 \mathrm{~cm} \mathrm{a}^{-1}$; Audry et al., 2004b).

\subsubsection{Dissolved trace metal profiles in pore waters}

The pore water profiles of trace metals $(\mathrm{Zn}, \mathrm{Cd}, \mathrm{Cu}, \mathrm{Pb})$ from the three cores show common features (Fig. 6: (i) release of trace metals in the dissolved phase below the water-sediment interface, resulting in concentration peaks in the uppermost $5 \mathrm{~cm}$ depth range; (ii) decreasing concentrations below the concentration peaks, reflecting removal processes. These features indicate post-depositional mobilization of trace metals and their redistribution within the sediment column. The peaks of trace metals are located in the depth range where denitrification proceeds and dissolved $\mathrm{Mn}$ and Fe concentrations increase (Fig. 5). This strongly suggests that trace metals are released in pore water from both OM degradation and reductive dissolution of $\mathrm{Mn}$ - and Fe-oxides. This result is in agreement with previous work on anoxic/sulfidic sediments in marine and freshwater systems (e.g. [Pedersen, 1985], [Shaw et al., 1994], [van den Berg et al., 1999] and [Audry et al., 2006a]).

The removal of trace metals from pore water can be ascribed to precipitation of various metalsulfides and/or co-precipitation/adsorption with Fe-sulfides, which is in good agreement with the high concentrations of trace metals in the oxidizable fraction in the sediment cores ([Fig. 7], [Fig. 8] and [Fig. 9]). Such behavior is consistent with the reported strong tendency of 
divalent metals to associate with sulfide minerals in anoxic sediments (Calvert and Pedersen, 1993; Morse and Luther III, 1999). Despite strongly anoxic conditions, Mn- and Fe-oxides are still present at depth in the three sediment cores (see Fig. 7), which is likely due to (i) high sedimentation rates precluding reductive dissolution of the whole pool of reactive oxides or (ii) the presence of less reactive $\mathrm{Mn}$ - and Fe-oxides. This observation is consistent with a broad maximum of ascorbate-extracted $\mathrm{Hg}$ at $\sim 20-60 \mathrm{~cm}$ depth in the Cajarc core (Castelle et al., 2007). Sorption of trace metals on Mn- and Fe-oxides ([Tessier et al., 1996] and [Morford and Emerson, 1999]) could therefore explain additional removal from solution.

\subsubsection{Chemical partitioning of metals in the solid fraction}

The chemical partitioning of $\mathrm{Fe}$ is quite homogeneous between and within the three cores ([Fig. 7] and [Fig. 8]). Iron shows low reactivity, principally being present in the RF $(\sim 90 \%)$, which may represent crystalline Fe-oxides (goethite and hematite) and Fe in silicate minerals. Operationally-defined reactive Fe is mostly found in the reducible fraction (7-10\%). This suggests that reactive $\mathrm{Fe}$ is mainly associated with amorphous oxides and/or oxyhydroxides, which is in agreement with SEM/EMPA observations for the Cajarc sediments and the abovediscussed pore water distributions. In contrast to $\mathrm{Fe}, \mathrm{Mn}$ shows higher reactivity, being mainly present in the reactive fractions (F1 + F2 + F3 $=63-77 \%$; Fig. 7). This could be related to the fact that $\mathrm{Mn}$ is generally associated with poorly ordered phases and occurs in different valence states, particularly in systems impacted by mining/smelting activities (Lee et al., 2002).

In contrast to $\mathrm{Fe}$, the chemical partitioning of the studied trace metals shows clear differences between the three cores: In the Marcenac core, while the total trace metal profiles show similar patterns, trace metal distributions between the reactive fractions depend on each metal ([Fig. 7] and [Fig. 8]). Apart from Cd, trace metals show low reactivity, being mainly associated with the RF fraction $(52 \%<\mathrm{RF}<83 \%$, on average). In contrast, Cd shows high reactivity, with very low contents in the RF fraction (18\% on average; Fig. 8$)$, and is mainly distributed between the exchangeable/carbonate ( $46 \%$ on average) and the oxidizable (31\% on average) fractions, while the contribution of the reducible fraction is low (6\% on average).

In the Cajarc core, trace metals show higher chemical reactivity compared to Marcenac, as suggested by the generally lower trace metal abundance in the RF fraction ([Fig. 7] and [Fig. 8]). The resulting higher reactivity is principally related to the higher average contribution of the oxidizable fraction (F3), e.g. 31-64\% for Cd and 11-59\% for $\mathrm{Zn}$. According to the ${ }^{137} \mathrm{Cs}-$ dating of the core (Audry et al., 2004b), the concentration peak observed for $\mathrm{Zn}, \mathrm{Cd}$ and $\mathrm{Pb}$ at $42 \mathrm{~cm}$ depth ([Fig. 7] and [Fig. 8]) is attributed to the accidental pollution that occurred in the Lot River watershed in 1986 (see above). Interestingly, the chemical partitioning of $\mathrm{Cu}$ in sediment affected by this pollution event shows a drastic increase in fraction F1, i.e. from $1 \%$ to $49 \%$. In contrast, the chemical partitioning of the other studied trace metals does not show any change at this particular depth.

In the Temple core, $\mathrm{Cu}$ is the least reactive trace metal, being mainly associated with the RF fraction (71\%; Fig. 8). All studied trace metals, except $\mathrm{Cd}$, are characterized by low reactivity (e.g. $\mathrm{RF} \approx 70 \%$ for $\mathrm{Zn}$ and $\mathrm{Pb}$; [Fig. 7] and [Fig. 8]) within the lowermost $15 \mathrm{~cm}$ of the core. The bottom of this core was identified as sediments (riverbed or former soil) deposited before the dam construction and/or not affected by the mining/smelting activity, with the overall trace metal distribution over depth suggesting that the Temple core may not represent a gapless historical record (Audry et al., 2004b). Above this zone, within the $25-75 \mathrm{~cm}$ depth 
range, trace metal $(\mathrm{Zn}, \mathrm{Pb})$ reactivity drastically increases, with the sum of the reactive fractions $(\mathrm{F} 1+\mathrm{F} 2+\mathrm{F} 3)$ reaching $85 \%(\mathrm{~Pb})$ and $95 \%(\mathrm{Zn})$ of the total concentrations. This increase is mainly related to the increase of both, fraction F1 (e.g. from $12 \%$ to $32 \%$ for $\mathrm{Zn}$ on average) and F3 (e.g. from $13 \%$ to $41 \%$ for $\mathrm{Zn}$ on average). This depth interval was identified as strongly influenced by inputs of highly-reactive materials originating from weathering of mining/smelting waste areas in the Riou Mort catchment (Audry et al., 2004b). The chemical partitioning of $\mathrm{Cd}$ is similar to that at Marcenac, except for the $25-50 \mathrm{~cm}$ depth range that was identified as the depth range impacted by the 1986 pollution accident (Audry et al., 2004b). Within this particular depth range, average Cd reactivity is lower than in the rest of the core, as the fractions F1 and F2 are minimized. For example, the average value of F1 drops from $50 \%$ in the upper core to $\sim 20 \%$ in the $25-50 \mathrm{~cm}$ depth range (Fig. 8 ).

\subsubsection{Post-depositional redistribution of metals}

The results from the chemical selective extractions in the sediments ([Fig. 7] and [Fig. 8]) were combined with information obtained from the vertical distribution of redox parameters and chemical partitioning in the suspended particulate matter (SPM) from the same sampling sites reported in Audry et al. (2006b) to assess the post-depositional redistribution of metals in the sediment of the three reservoirs. Mineralization of OM favors authigenesis of Fe-sulfides in the studied reservoir sediments inducing post-depositional redistribution of $\mathrm{Fe}$ as discussed earlier. However, the contribution of the oxidizable fraction (F3) in the sediments is low, even at depth $(<2 \%$; [Fig. 7] and [Fig. 8]). All this suggests that authigenic Fe is (partly) pyritized at depth, which is in agreement with the SEM/EMPA results showing the presence of pyrite in the Cajarc sediments (not shown).

Mean chemical partitioning of trace metals in the upstream Lot River (Marcenac site) in sediment and SPM is similar (Fig. 9). It is dominated by the RF fraction ( $\sim 80 \%$ for $\mathrm{Pb}, \sim 70 \%$ for $\mathrm{Cu}, \sim 40-50 \%$ for $\mathrm{Zn}$ and $\sim 40-20 \%$ for $\mathrm{Cd}$ ). The other major contributing fraction is $\mathrm{F} 1$ for $\mathrm{Cd}$ and $\mathrm{Zn}(\sim 40 \%$ and $\sim 20 \%$, respectively), $\mathrm{F} 2$ for $\mathrm{Pb}(\sim 10 \%)$ and $\mathrm{F} 3$ for $\mathrm{Cu}(10-20 \%)$. This partitioning suggests low reactivity of trace metal-bearing phases observed in both SPM and reservoir sediments from the upstream Lot River inducing a rather low post-depositional redistribution of trace metals.

SPM settling in the Cajarc reservoir originates from the upstream Lot River (95\%) and the Riou Mort River (5\%) (Audry et al., 2004a). The chemical partitioning of the SPM from the Riou Mort River (Audry et al., 2006b) differs from that of the upstream Lot River: Zn and Cd are mainly present in the F1 fraction $(>60 \%)$ and the RF fraction is lower than $2 \%$. Copper and $\mathrm{Pb}$ are principally bound to the RF fraction $(\sim 70 \%), \mathrm{F} 2(15 \%$; Pb) and $\mathrm{F} 3(23 \%$; $\mathrm{Cu})$. In contrast to the Marcenac sediments, intense post-depositional redistribution of trace metals is observed in Cajarc sediments as shown by the clearly higher contribution of the F3 fraction in sediments (e.g. $59 \%$ for $\mathrm{Zn}, 65 \%$ for $\mathrm{Cd}, 40 \%$ for $\mathrm{Cu}, 22 \%$ for $\mathrm{Pb}$ on average; Fig. 9) compared to those in SPM from the same site (e.g. $29 \%$ for $\mathrm{Zn}, 24 \%$ for $\mathrm{Cd}$ and $\mathrm{Cu}, 3 \%$ for $\mathrm{Pb}$ on average; Fig. 9).

The SEM/EDS and EMPA analyses show that in the waste areas, trace metals are mainly associated with spinels, silicates and sulfates (Table 3), whereas in the Cajarc sediments, Znsulfides were abundant (with other discrete metal-sulfides, such as $\mathrm{CdS}, \mathrm{PbS}, \mathrm{CuS}$ ). This suggests intense sulfide formation in the Cajarc sediments that probably sequestrated trace metals from pore water, resulting in the observed increase in the F3 fraction of these sediments. This stronger post-depositional redistribution of trace metals towards sulfide 
phases in the Cajarc sediments compared to the Marcenac sediments may be attributed to two main factors both promoting stronger sulfides authigenesis: (i) threefold

higher $\mathrm{SO}_{4}^{2-}$ concentrations in bottom water and pore water (Fig. 5) and (ii) higher reactivity (particularly for $\mathrm{Zn}$ and $\mathrm{Cd}$ ) of trace metal-bearing phases in SPM of anthropogenic origin (i.e. derived from the Riou Mort watershed; see above) settling on the water-sediment interface. Additionally, the average oxidizable Fe fraction (i.e. $590 \mathrm{mg} \mathrm{kg}^{-1}$ ) is lower than that of $\mathrm{Zn}$ $\left(2530 \mathrm{mg} \mathrm{kg}^{-1}\right)$. All this suggests that a part of the trace metals in the Cajarc sediments are redistributed by early diagenetic processes, mainly by reductive dissolution and coprecipitation with $\mathrm{Fe}$ - and $\mathrm{Zn}$-sulfides (e.g. ZnS may form in contaminated sediments; Zaggia and Zonta, 1997). Part of the trace metals released into pore water may also adsorb onto authigenic Fe-sulfides (Morse and Luther III, 1999) and eventually be solubilized during the F3 leaching, while the carrier phase is not. Detrital Zn-sulfides were recognized in small amounts in the Cajarc sediments (see above) and could also contribute to trace metal content in the oxidizable fraction. Finally, one cannot exclude a contribution of other phases than authigenic sulfides (e.g. OM) to the high content of trace metals in the oxidizable fraction of the Cajarc sediments. However, the quantity of trace metals leached from OM would be expected to be small, because burial and subsequent OM degradation are likely to have decreased the amount of metals associated with reactive organic matter ([Widerlund, 1996] and [Audry et al., 2006a]).

Similarly to Cajarc, the higher mean trace metal contribution of the F3 fraction in sediment (e.g. $31.5 \%$ for $\mathrm{Zn}$ and $9.4 \%$ for $\mathrm{Pb}$ ) compared to that in SPM (22.3\% for $\mathrm{Zn}$ and $1.8 \%$ for $\mathrm{Pb}$; (Audry et al., 2006b) at the Temple site is assigned to post-depositional redistribution of trace metals towards authigenic sulfide phases. Note that direct inputs of authigenic sulfides from Cajarc sediments, due to dam flushing or floods, could account for additional oxidizable inputs of trace metals into the Temple sediments (transport distance $\sim 150 \mathrm{~km}$ ). The contrasting behavior of $\mathrm{Cd}$, in comparison to that of $\mathrm{Zn}$ or $\mathrm{Pb}$, may eventually be attributed to intense post-depositional redistribution of reactive $\mathrm{Cd}$ with more specific sequestration by $\mathrm{Fe}-$ sulfide phases non-extractible by the $\mathrm{H}_{2} \mathrm{O}_{2}$ leaching.

\subsection{Environmental concerns}

Due to weathering of secondary sulfate phases observed in the waste areas, likely along with oxidation of relict sulfides, the Riou Mort River shows high $\mathrm{SO}_{4}^{2-}$ concentrations (up to $1200 \mathrm{mg} \mathrm{L}^{-1}$; Audry et al., 2005). Therefore, while representing only $0.5 \%$ and $1.5 \%$, respectively, of the water and SPM fluxes of the downstream Garonne River (La Réole site; Fig. 1; Audry et al., 2004a), the Riou Mort River impacts the whole Lot-Garonne River system by contributing $\sim 20 \%$ to the $\mathrm{SO}_{4}^{2-}$ fluxes (Audry et al., 2005) and 50-60\% and $\sim 20 \%$ to the total (dissolved + particulate) fluxes of Cd and Zn, respectively (Audry et al., 2004a). A major consequence of these inputs via the Riou Mort River is the clearly higher supply of $\mathrm{SO}_{4}^{2-}$ (Fig. 5) and reactive trace metals ([Fig. 7] and [Fig. 8]) to the water-sediment interface at the Cajarc and Temple sites compared to the Marcenac site. This may strongly enhance the post-depositional redistribution of trace metals by promoting increased dissolved sulfide production through $\mathrm{SO}_{4}^{2-}$ reduction and increased co-precipitation of trace metals with diagenetic sulfide phases in the sediments. Precipitation of diagenetic sulfide phases, however, may only provide definitive sequestration of trace metals under permanently anoxic conditions. Resuspension of anoxic sediments by natural (floods) and anthropogenic (dredging, dam flush) processes favors their exposure to oxidizing environments, and therefore can contribute to fast mobilization (hour time-scale; Saulnier and Mucci, 2000) of 
trace metals to the water column. The oxidizable fraction (F3) of the anoxic sediments could be particularly affected by resuspension events.

Coynel et al. (2007) reported that up to $50 \mathrm{~cm}$ depth of Cajarc and Temple reservoir sediments could be resuspended during a major ( 1 in 100 a) flood event. Rough estimates were made of potential trace metal release into the water column from sulfide phases for two scenarios: (1) $50 \mathrm{~cm}$ depth of sediment resuspended and (2) total resuspension of the sediments. These estimations were done assuming a negligible contribution of OM to the F3 fraction (as discussed earlier). According to data for sediment depths in Cajarc and Temple reservoirs reported in Lapaquellerie et al. (1995) and the present authors' observations, it was assumed that a $50 \mathrm{~cm}$ depth resuspension of sediment would correspond to a resuspension of $2 / 5$ (Cajarc) and 2/3 (Temple) of the sediment pile. For the Cajarc sediments, the following average contribution of the F3 fraction to TMC was used: $65 \%(\mathrm{Cd}), 59 \%(\mathrm{Zn}), 40 \%(\mathrm{Cu})$, and $22 \%(\mathrm{~Pb})$. However, for the Temple sediments, two average contributions of the F3 fraction were considered for each scenario in order to take into account the depth variability of the oxidizable fraction ([Fig. 7] and [Fig. 8]). For scenario 1, the following average F3 contributions were used: $26 \%(\mathrm{Cd}), 21 \%(\mathrm{Zn}), 15 \%(\mathrm{Cu})$, and $3.5 \%(\mathrm{~Pb})$ for the $0-25 \mathrm{~cm}$ depth interval and $35 \%(\mathrm{Cd}), 44 \%(\mathrm{Zn}), 25 \%(\mathrm{Cu})$, and $13 \%(\mathrm{~Pb})$ for the $25-50 \mathrm{~cm}$ depth interval. Each depth interval was considered as representing $50 \%$ of the sediments potentially resuspended. For scenario 2 , the $0-25 \mathrm{~cm}$ depth interval was assumed to represent $1 / 3$ of the sediments potentially resuspended and the same contributions of the F3 fraction as for scenario 1 were used. The following contributions of the F3 fraction were considered for the $25-75 \mathrm{~cm}$ depth interval which is assumed to represent $2 / 3$ of the resuspendable sediments: $36 \%(\mathrm{Cd}), 39 \%(\mathrm{Zn}), 23 \%(\mathrm{Cu})$, and $13 \%(\mathrm{~Pb})$. The potential release of trace metals into the water column from oxidation of sulfide phases was then estimated for the Cajarc and Temple reservoirs (Table 5) using these average F3 fraction contributions and the trace metal inventory reported in Audry et al. (2004b).

Combining resuspension-induced release of trace metals in the Cajarc and Temple reservoirs suggests that about $870 \mathrm{t}$ of $\mathrm{Zn}, 25 \mathrm{t}$ of $\mathrm{Pb}, 18 \mathrm{t}$ of $\mathrm{Cd}$ and $17 \mathrm{t}$ of $\mathrm{Cu}$ could be released to the Lot River during a major flood event (scenario 1). These amounts of trace metals are 13-fold $(\mathrm{Cd}), 6$-fold $(\mathrm{Zn}), 4$-fold $(\mathrm{Pb})$ higher than and $2 / 3(\mathrm{Cu})$ of the respective mean annual inputs of dissolved trace metals into the Gironde estuary (i.e. $137 \mathrm{t} \mathrm{a}^{-1}$ for $\mathrm{Zn}, 40 \mathrm{t} \mathrm{a}^{-1}$ for $\mathrm{Cu}, 5.8 \mathrm{t} \mathrm{a}^{-1}$ for $\mathrm{Pb}$ and $1.3 \mathrm{t} \mathrm{a}^{-1}$ for $\mathrm{Cd}$; Masson et al., 2006). Total resuspension of Cajarc and Temple sediments (scenario 2) would lead to the release of $1540 \mathrm{t}$ of $\mathrm{Zn}, 51 \mathrm{t}$ of $\mathrm{Pb}, 33 \mathrm{t}$ of $\mathrm{Cd}$ and $31 \mathrm{t}$ of $\mathrm{Cu}$. These amounts of trace metals are 25 -fold $(\mathrm{Cd}), \sim 10$-fold $(\mathrm{Zn}, \mathrm{Pb})$ higher than and similar to $(\mathrm{Cu})$ the respective mean annual inputs of dissolved trace metals into the Gironde estuary. However, for either scenario 1 or 2 , the final amounts of dissolved trace metals released into the water column would depend on the reactivity of the carrier phases and competition between release and removal processes: For example, formation of metal-organic complexes with hydrophobic (C18-extracted) organic phases in the water column of the Lot River (Lemaire et al., 2006) could contribute to partly stabilize dissolved trace metals (e.g. $\mathrm{Cu}$, $\mathrm{U})$ and thus favor their export to the Gironde estuary in the dissolved phase. However, one cannot exclude that part of the resuspended sulfide phases would rapidly settle down (low energy areas) before having released all of the potentially-releasable trace metals, although once these particles reach the Gironde estuary they would be expected to undergo intense sedimentation/resuspension cycles (Abril et al., 1999). Precipitation in the water column of Fe- and Mn-oxyhydroxides using dissolved Fe and Mn, either derived from solid sulfide oxidation or pore water from sediments (e.g. [Simpson et al., 1998], [Simpson et al., 2000] and [Saulnier and Mucci, 2000]) could also induce scavenging of released trace metals by the 
freshly precipitated Fe- and Mn-oxyhydroxides. Scavenging of dissolved trace metals could also be enhanced by sorption onto clay minerals present in SPM. Regarding Pb, resuspensioninduced precipitation of low-soluble Pb-sulphate (e.g. anglesite) would likely occur at houror day-scales (Marani et al., 1995) in the water column. This would favor Pb scavenging and back settling to the sediment thus moderating $\mathrm{Pb}$ export to downstream areas. Although under oxic freshwater conditions most of these processes would tend to decrease the part of dissolved trace metals transported into the Gironde estuary, the impact of trace metals released from reservoir sediments and transported to the coastal zone will mainly depend on their recycling and transformation in the estuarine geochemical gradients (e.g. salinity, redox, turbidity; [Robert et al., 2004], [Audry et al., 2006a] and [Audry et al., 2007]).

\section{Conclusions}

This study of sediment cores from three reservoirs of the Lot River indicates a profound anthropogenic, mining waste-related impact on the chemical partitioning of trace metals in reservoir sediment upstream and downstream of a mining/smelting activity impacted watershed. This point source provides trace metal-rich particles characterized by heterogeneous mineral compositions with highly variable contents of trace metals. The main trace metal-bearing phases included zincian spinels, silicates and secondary sulfates.

Post-depositional redistribution of trace metals in reservoir sediments is related to bacteriallymediated organic matter oxidation and accompanying processes, including dissolution of the initial trace metal-bearing phases and subsequent sequestration by authigenic sulfide phases. Enhanced post-depositional redistribution in the downstream sediments is ascribed to greater supplies (derived from the weathering of the mining/smelting wastes) at the water-sediment interface of (i) $\mathrm{SO}_{4}^{2-}$ promoting more efficient organic matter oxidation, and authigenic sulfide formation and (ii) highly reactive trace metal-bearing particles. Accordingly, SEMEDS and EMPA analyses indicate that the main trace metal-bearing phases in these sediments are represented by $\mathrm{Zn}$ - and Fe-sulfides, but trace metals are also sequestered in $\mathrm{Zn}$-sulfates, Fe-oxyhydroxides and, to a lesser extent, in herited zincian spinels.

Deeper in the contaminated reservoir sediments, trace metal sequestration by authigenic sulfides represents only a temporary sink (as long as the sediments remains anoxic), due to the risk of sediment resuspension by natural (floods) and anthropogenic (dredging, dam flush) events, inducing oxidation of these reduced phases and thus mobilization of the associated trace metals. It was estimated that the amounts of trace metals possibly mobilized due to sediment resuspension during a major flood event from the two studied downstream reservoirs in the Lot River could be 13-fold $(\mathrm{Cd}), \sim 6$-fold $(\mathrm{Zn}), 4$-fold $(\mathrm{Pb})$ the mean annual inputs of the respective dissolved trace metals into the Gironde estuary. This work shows the value of including mineralogical characterization of the solid phases in studies dealing with environmental impacts of anthropogenic activities in river sediments. Mineral characterization provides valuable information on the presence of reactive authigenic phases in the sediment and on the way primary and/or secondary mineral phases of anthropogenic origin can be weathered and release trace metals during diagenetic processes. This work clearly highlights the need for sediment management strategies taking into account the specific geochemical and mineralogical processes occurring in mining-impacted reservoir sediments that bear severe risks to water quality of various aquatic systems at the global scale.

\section{Acknowledgments}


This study is a scientific contribution of the 'GIS ECOBAG' (Groupement d'Intérêt Scientifique: Ecologie du Bassin Adour-Garonne). This work was supported by grants from 'l'Agence de l'Eau Adour-Garonne', 'le Ministère de la Recherche', 'le Conseil Régional du Limousin' and 'le FEDER-Région Aquitaine'. The assistance of the following colleagues covering various aspects of the field and laboratory work is gratefully acknowledged: C. Bossy, Y. Lapaquellerie, G. Chaillou, G. Lavaux, J. P. Lissalde, P. Anschutz, N. Maillet, and M. Peymirat. We sincerely thank M. Fialin and F. Couffignal for their assistance on EMPA analyses and P. Carles for his technical help with SEM observations.

\section{References}

Abril et al., 1999 G. Abril, H. Etcheber, P. Le Hir, P. Bassoullet, B. Boutier and M. Frankignoulle, Oxic/anoxic oscillations and organic carbon mineralization in an estuarine maximum turbidity zone (The Gironde, France), Limnol. Oceanog. 44 (1999), pp. 1304-1315.

AFNOR, 1996 AFNOR, NF ISO 10304-2, Dosage d'ions $\left(\mathrm{F}^{-}, \mathrm{Cl}^{-}, \mathrm{NO}^{2-}, \mathrm{NO}^{3-}, \mathrm{Br}^{-}, \mathbf{P O}_{4}^{3-}\right.$ et $\mathrm{SO}_{4}^{2-}$ ) par chromatographie des ions en phase liquide. Partie 1: méthode applicable pour les eaux usées (1996), pp. 171-196.

Aller and Rude, 1988 R.C. Aller and P.D. Rude, Complete oxidation of solid phase sulfides by manganese and bacteria in anoxic marine sediments, Geochim. Cosmochim. Acta 52 (1988), pp. 751-765.

Anderson, 1979 L. Anderson, Simultaneous spectrophotometric determination of nitrite and nitrate by flow injection analysis, Anal. Chim. Acta 110 (1979), pp. 123-128.

Antunes et al., 2002 I.M.H.R. Antunes, A.M.R. Neiva and M.M.V.G. Silva, The mineralized veins and the impact of old mine workings on the environment at Segura, central Portugal, Chem. Geol. 190 (2002), pp. 417-431.

Audry et al., 2007 S. Audry, G. Blanc, J. Schäfer, F. Guérin, M. Masson and S. Robert, Budgets of $\mathrm{Mn}, \mathrm{Cd}$ and $\mathrm{Cu}$ in the macrotidal Gironde estuary (SW France), Mar. Chem. 107 (2007), pp. 433-448.

Audry et al., 2006a S. Audry, G. Blanc, J. Schäfer, G. Chaillou and S. Robert, Early diagenesis of trace metals $(\mathrm{Cd}, \mathrm{Cu}, \mathrm{Co}, \mathrm{Ni}, \mathrm{U}, \mathrm{Mo}$, and $\mathrm{V})$ in the freshwater reaches of a macrotidal estuary, Geochim. Cosmochim. Acta 70 (2006), pp. 2264-2282.

Audry et al., 2006b S. Audry, G. Blanc and J. Schafer, Solid state partitioning of trace metals in suspended particulate matter from a river system affected by smelting-waste drainage, $S c i$. Total Environ. 363 (2006), pp. 216-236.

Audry et al., 2005 S. Audry, G. Blanc and J. Schäfer, The impact of sulphide oxidation on dissolved metal $(\mathrm{Cd}, \mathrm{Zn}, \mathrm{Cu}, \mathrm{Cr}, \mathrm{Co}, \mathrm{Ni}, \mathrm{U})$ inputs into the Lot-Garonne fluvial system (France), Appl. Geochem. 20 (2005), pp. 919-931.

Audry et al., 2004a S. Audry, J. Schäfer, G. Blanc, C. Bossy and G. Lavaux, Anthropogenic components of heavy metal $(\mathrm{Cd}, \mathrm{Zn}, \mathrm{Cu}, \mathrm{Pb})$ budgets in the Lot-Garonne fluvial system (France), Appl. Geochem. 19 (2004), pp. 769-786. 
Audry et al., 2004b S. Audry, J. Schäfer, G. Blanc and J.-M. Jouanneau, Fifty-year sedimentary record of heavy metal pollution $(\mathrm{Cd}, \mathrm{Zn}, \mathrm{Cu}, \mathrm{Pb})$ in the Lot River reservoirs (France), Environ. Pollut. 132 (2004), pp. 413-426.

Battacharya and Gupta, 2008 K.G. Battacharya and S.S. Gupta, Adsorption of a few heavy metals on natural and modified kaolinite and montmorillonite: a review, Adv. Colloid Interf. Sci. 40 (2008), pp. 114-131.

Berner, 1980 R.A. Berner, Early Diagenesis: A Theoretical Approach, Princeton University Press, New York (1980).

Bird et al., 2003 G. Bird, P.A. Brewer, M.G. Macklin, D. Balteanu, B. Driga, M. Serban and S. Zaharia, The solid state partitioning of contaminant metals and As in river channel sediments of the mining affected Tisa drainage basin, northwestern Romania and eastern Hungary, Appl. Geochem. 18 (2003), pp. 1583-1595.

Blanc et al., 199 G. Blanc, Y. Lapaquellerie, N. Maillet and P. Anschutz, A cadmium budget for the Lot-Garonne fluvial system (France), Hydrobiologia 410 (1999), pp. 331-341.

Blowes et al., 1998 D.W. Blowes, J.L. Jambor, C.J. Hanton-Fong, L. Lortie and W.D. Gould, Geochemical, mineralogical and microbiological characterization of a sulphide-bearing carbonate-rich gold-mine tailings impoundment, Joutel, Quebec. Appl. Geochem. 13 (1998), pp. 687-705.

Böttcher and Thamdrup, 2001 M.E. Böttcher and B. Thamdrup, Anaerobic sulfide oxidation and stable isotope fractionation associated with bacterial sulfur disproportionation in the presence of $\mathrm{MnO}_{2}$, Geochim. Cosmochim. Acta 65 (2001), pp. 1573-1581.

Boutier, 1981 B. Boutier, Synthèse des résultats de la surveillance des micropolluants dans la matière vivante, Ministère de l'Environ. Bull. Réseau Nat. d'Observ. 17 (1981), pp. 115-174.

Buban et al., 1999 K.R. Buban, M.J. Collins and I.M. Masters, Iron controls in zinc pressure leach processes, JOM 51 (1999), pp. 23-25.

Calvert and Pedersen, 1993 S.E. Calvert and T.F. Pedersen, Geochemistry of recent oxic and anoxic marine sediments: Implications for the geological record, Mar. Geol. 113 (1993), pp. $67-88$.

Castelle et al., 2007 S. Castelle, J. Schafer, G. Blanc, S. Audry, H. Etcheber and J.-P. Lissalde, Fifty-year record and solid state speciation of mercury in natural and contaminated reservoir sediment, Appl. Geochem. 22 (2007), pp. 1359-1370.

Cauwet et al., 1990 G. Cauwet, F. Gadel, M.M. de Souza Sierra, O. Donard and M. Ewald, Contribution of the Rhone River to organic carbon inputs to the northwestern Mediterranean Sea, Continent. Shelf Res. 10 (1990), pp. 1025-1037.

Chaillou et al., 2002 G. Chaillou, P. Anschutz, G. Lavaux, J. Schäfer and G. Blanc, The distribution of Mo, $\mathrm{U}$, and $\mathrm{Cd}$ in relation to major redox species in muddy sediments of the Bay of Biscay, Mar. Chem. 80 (2002), pp. 41-59. 
Chaplygin et al., 2007 I.V. Chaplygin, N.N. Mozgova, A.V. Mokhov, E.V. Koporulina, H.-J. Bernhardt and I.A. Bryzgalov, Minerals of the system $\mathrm{ZnS}-\mathrm{CdS}$ from fumaroles of the Kudriavy volcano, Iturup Island, Kuriles, Russia Can. Mineral. 45 (2007), pp. 709-722.

Claassen et al., 2002 J.O. Claassen, E.H.O. Meyer, J. Rennie and R.F. Sandenbergh, Iron precipitation from zinc-rich solutions: defining the Zincor process, Hydrometallurgy $\mathbf{6 7}$ (2002), pp. 87-108.

Courtin-Nomade et al., 2003 A. Courtin-Nomade, H. Bril, C. Neel and J.-F. Lenain, Arsenic in iron cements developed within tailings of a former metalliferous mine-Enguiales, Aveyron, France Appl. Geochem. 18 (2003), pp. 395-408.

Coynel et al., 2007 A. Coynel, J. Schafer, G. Blanc and C. Bossy, Scenario of particulate trace metal and metalloid transport during a major flood event inferred from transient geochemical signals, Appl. Geochem. 22 (2007), pp. 821-836.

Dold and Fontbote, 2002 B. Dold and L. Fontbote, A mineralogical and geochemical study of element mobility in sulfide mine tailings of $\mathrm{Fe}$ oxide $\mathrm{Cu}-\mathrm{Au}$ deposits from the Punta del Cobre belt, northern Chile, Chem. Geol. 189 (2002), pp. 135-163.

Ettler et al., 2003 V. Ettler, Z. Johan and D. Hradil, Natural alteration products of sulphide mattes from primary lead smelting, C. R. Geoscience 335 (2003), pp. 1013-1020.

Fialin et al., 1999 M. Fialin, H. Remy, C. Richard and C. Wagner, Trace element analysis with the electron microprobe: new data and perspectives, Am. Mineral. 84 (1999), pp. 70-77.

Froelich et al., 1979 P.N. Froelich, G.P. Klinkhammer, M.L. Bender, N.A. Luedtke, G.R. Heath, D. Cullen, P. Dauphin, D. Hammond, B. Hartman and V. Maynard, Early oxidation of organic matter in pelagic sediments of the eastern equatorial Atlantic: suboxic diagenesis, Geochim. Cosmochim. Acta 43 (1979), pp. 1075-1090.

Galan et al., 2003 E. Galan, J.L. Gomez-Ariza, I. Gonzalez, J.C. Fernandez-Caliani, E. Morales and I. Giraldez, Heavy metal partitioning in river sediments severely polluted by acid mine drainage in the Iberian Pyrite Belt, Appl. Geochem. 18 (2003), pp. 409-421.

Gieré et al., 2003 R. Gieré, N.V. Sidenko and E.V. Lazareva, The role of secondary minerals in controlling the migration of arsenic and metals from high-sulfide wastes (Berikul gold mine, Siberia), Appl. Geochem. 18 (2003), pp. 1347-1359.

Graupner et al., 2007 T. Graupner, A. Kassahun, D. Rammlmair, J.A. Meima, D. Kock, M. Furche, A. Fiege, A. Schippers and F. Melcher, Formation of sequences of cemented layers and hardpans within sulfide-bearing mine tailings (mine district Freiberg, Germany), Appl. Geochem. 22 (2007), pp. 2486-2508.

Grosbois et al., 2007 C. Grosbois, A. Courtin-Nomade, F. Martin and H. Bril, Transportation and evolution of trace element bearing phases in stream sediments in a mining - influenced basin (Upper Isle River, France), Appl. Geochem. 22 (2007), pp. 2362-2374. 
Grousset et al., 1999 F.E. Grousset, J.M. Jouanneau, P. Castaing, G. Lavaux and C. Latouche, A 70 year record of contamination from industrial activity along the Garonne River and its Tributaries (SW France), Estuar. Coast. Shelf Sci. 48 (1999), pp. 401-414.

Hall and Aller, 1992 P.O.J. Hall and R.C. Aller, Rapid, small-volume, flow injection analysis for $\mathrm{CO}_{2}$, and $\mathrm{NH}_{4}$ in marine and fresh waters, Limnol. Oceanog. 37 (1992), pp. 1113-1119.

Hammarstrom et al., 2005 J.M. Hammarstrom, R.R. Seal II, A.L. Meier and J.M. Kornfeld, Secondary sulfate minerals associated with acid drainage in the eastern US: recycling of metals and acidity in surficial environments, Chem. Geol. 215 (2005), pp. 407-431.

Hansen et al., 1981 L.D. Hansen, D. Silberman and G.L. Fisher, Crystalline components of stack-collected, size-fractionated coal fly ash, Environ. Sci. Technol. 15 (1981), pp. 10571062 .

Hitzman et al., 2003 M.W. Hitzman, N.A. Reynolds, D.F. Sangster, C.R. Allen and C.E. Carman, Classification, genesis, and exploration guides for nonsulfide zinc deposits, Econ. Geol. 98 (2003), pp. 685-714.

Hudson-Edwards et al., 2005 K.A. Hudson-Edwards, H.E. Jamieson, J.M. Charnock and M.G. Macklin, Arsenic speciation in waters and sediment of ephemeral floodplain pools, Rios Agrio-Guadiamar, Aznalcollar, Spain. Chem. Geol. 219 (2005), pp. 175-192

Hudson-Edwards et al., 1999 K.A. Hudson-Edwards, C. Schell and M.G. Macklin, Mineralogy and geochemistry of alluvium contaminated by metal mining in the Rio Tinto area, southwest Spain, Appl. Geochem. 14 (1999), pp. 1015-1030.

Isaure et al., 2002 M.-P. Isaure, A. Laboudigue, A. Manceau, G. Sarret, C. Tiffreau, P. Trocellier, G. Lamble, J.-L. Hazemann and D. Chateigner, Quantitative Zn speciation in a contaminated dredged sediment by [mu]-PIXE, [mu]-SXRF, EXAFS spectroscopy and principal component analysis, Geochim. Cosmochim. Acta 66 (2002), pp. 1549-1567

Iversen and Jørgensen, 1985 N. Iversen and B.B. Jørgensen, Anaerobic methane oxidation rates at the sulfate-methane transition in marine sediments from Kattegat and Skagerrak (Denmark), Limnol. Oceanog. 30 (1985), pp. 944-955.

Jak et al., 2002 E. Jak, B. Zhao and P. Hayes, Experimental study of phase equilibria in the "FeO"- $\mathrm{ZnO}-\left(\mathrm{CaO}+\mathrm{SiO}_{2}\right)$ system with $\mathrm{CaO} / \mathrm{SiO}_{2}$ weight ratios of $0.33,0.93$, and 1.2 in equilibrium with metallic iron, Metall. Mater. Trans. B 33 (2002), pp. 877-890.

Jambor, 1994 J.L. Jambor, Mineralogy of sulfide-rich tailings and their oxidation products. In: D.W. Blowes and J.L. Jambor, Editors, The Environmental Geochemistry of Sulfide MineWastes. Short Course Handbook, Mineralogical Association of Canada, Waterloo (1994), pp. 59-102.

Kierczak et al., 2009 J. Kierczak, C. Neel, J. Puziewicz and H. Bril, The mineralogy and weathering of slag produced by the smelting of lateritic Ni ores, Szklary, southwestern Poland, Can. Mineral. 47 (2009), pp. 557-572. 
Kostka and Luther, 1994 J.E. Kostka and G.W. Luther III, Partitioning and speciation of solid phase iron in saltmarsh sediments, Geochim. Cosmochim. Acta 58 (1994), pp. 1701-1710.

Kucha et al., 1996 H. Kucha, A. Martens, R. Ottenburgs, W. De Vos and W. Viaene, Primary minerals of $\mathrm{Zn}-\mathrm{Pb}$ mining and metallurgical dumps and their environmental behavior at Plombières, Belgium Environ. Geol. 27 (1996), pp. 1-15.

Kukier et al., 2003 U. Kukier, C.F. Ishak, M.E. Sumner and W.P. Miller, Composition and element solubility of magnetic and non-magnetic fly ash fractions, Environ. Pollut. 123 (2003), pp. 255-266.

Lapaquellerie et al., 1995 Y. Lapaquellerie, J.-M. Jouanneau, N. Maillet and C. Latouche, Cadmium pollution in sediments of the Lot River (France) and estimate of the mass of cadmium, Environ. Technol. 16 (1995), pp. 1145-1154.

Laperche and Bigham, 2002 V. Laperche and J.M. Bigham, Quantitative, chemical, and mineralogical characterization of flue gas desulfurization by-products, J. Environ. Qual. 31 (2002), pp. 979-988.

Lee et al., 2002 G. Lee, J.M. Bigham and G. Faure, Removal of trace metals by coprecipitation with $\mathrm{Fe}, \mathrm{Al}$ and $\mathrm{Mn}$ from natural waters contaminated with acid mine drainage in the Ducktown Mining District, Tennessee. Appl. Geochem. 17 (2002), pp. 569-581.

Lee et al., 2005 J.-S. Lee, H.-R. Wangle, Y. Ilzuka and S.-C. Yu, Crystal structure and Raman spectral studies of $\mathrm{BaSO}_{4}-\mathrm{PbSO}_{4}$ solid solution, Zeitschrift fur Kristallographie 220 (2005), pp. 1-9.

Lemaire et al., 2006 E. Lemaire, G. Blanc, J. Schäfer, A. Coynel and H. Etcheber, Dissolved trace metal-organic complexes in the Lot-Garonne River system determined using the C18 Sep-Pak System, Aquat. Geochem. 12 (2006), pp. 21-38.

Loan et al., 2006 M. Loan, O.M.G. Newman, R.M.G. Cooper, J.B. Farrow and G.M. Parkinson, Defining the Paragoethite process for iron removal in zinc hydrometallurgy, Hydrometallurgy 81 (2006), pp. 104-129.

Lottermoser and Cairns, 2005 B.G. Lottermoser and Cairns,, Evaporative mineral precipitates from a historical smelting slag dump, Rio Tinto, Spain, Neues Jahrbuch für Mineralogie Abhandlungen 181 (2005), pp. 183-190.

Lovley, 1997 D.R. Lovley, Microbial Fe(III) reduction in subsurface environments, FEMS Microbiol. Rev. 20 (1997), pp. 305-313.

Ma and Uren, 1995 Y.B. Ma and N.C. Uren, Application of a new fractionation scheme for heavy metals in soils, Commun. Soil Sci. Plant Anal. 26 (1995), pp. 3291-3303.

Marani et al., 1995 D. Marani, G. Macchi and M. Pagano, Lead precipitation in the presence of sulphate and carbonate: testing of thermodynamic predictions, Water Res. 29 (1995), pp. 1085-1092. 
Masson et al., 2006 M. Masson, G. Blanc and J. Schäfer, Geochemical signals and source contributions to heavy metal $(\mathrm{Cd}, \mathrm{Zn}, \mathrm{Pb}$, and $\mathrm{Cu})$ fluxes into the Gironde Estuary via its major tributaries, Sci. Total Environ. 370 (2006), pp. 133-146.

McGregor and Blowes, 2002 R.G. McGregor and D.W. Blowes, The physical, chemical and mineralogical properties of three cemented layers within sulfide-bearing mine tailings, $J$. Geochem. Explor. 76 (2002), pp. 195-207.

McGregor et al., 1998 R.G. McGregor, D.W. Blowes, J.L. Jambor and W.D. Robertson, The solid-phase controls on the mobility of heavy metals at the copper cliff tailings area, Sudbury, Ontario, Can. J. Contam. Hydrol. 33 (1998), pp. 247-271.

Moncur et al., 2005 M.C. Moncur, C.J. Ptacek, D.W. Blowes and J.L. Jambor, Release, transport and attenuation of metals from an old tailings impoundment, Appl. Geochem. 20 (2005), pp. 639-659.

Morford and Emerson, 1999 J.L. Morford and S. Emerson, The geochemistry of redox sensitive trace metals in sediments, Geochim. Cosmochim. Acta 63 (1999), pp. 1735-1750.

Morillo et al., 2002 J. Morillo, J. Usero and I. Gracia, Partitioning of metals in sediments from the Odiel River (Spain), Environ. Internat. 28 (2002), pp. 263-271.

Morse and Luther, 1999 J.W. Morse and G.W. Luther III, Chemical influences on trace metalsulfide interactions in anoxic sediments, Geochim. Cosmochim. Acta 63 (1999), pp. 33733378 .

Nickel, 1995 E.H. Nickel, The definition of a mineral, Can. Mineral. 33 (1995), pp. 689-690.

Niewohner et al., 1998 C. Niewohner, C. Hensen, S. Kasten, M. Zabel and H.D. Schulz, Deep sulfate reduction completely mediated by anaerobic methane oxidation in sediments of the upwelling area off Namibia, Geochim. Cosmochim. Acta 62 (1998), pp. 455-464.

Parsons et al., 2001 M.B. Parsons, D.K. Bird, M.T. Einaudi and C.N. Alpers, Geochemical and mineralogical controls on trace element release from the Penn Mine base-metal slag dump, California Appl. Geochem. 16 (2001), pp. 1567-1593.

Pedersen, 1985 T.F. Pedersen, Early diagenesis of copper and molybdenum in mine tailings and natural sediments in Rupert and Holberg inlets, British Columbia, Can. J. Earth Sci. 22 (1985), pp. 1474-1484.

Piatak et al., 2004 N.M. Piatak, I. Seal, R. Robert and J.M. Hammarstrom, Mineralogical and geochemical controls on the release of trace elements from slag produced by base- and precious-metal smelting at abandoned mine sites, Appl. Geochem. 19 (2004), pp. 1039-1064.

Pooley, 2004 G.D. Pooley, Secondary and backscattered electron imaging of weathered chromian spinel, Scanning 26 (2004), pp. 240-249.

Postma and Jakobsen, 1996 D. Postma and R. Jakobsen, Redox zonation: equilibrium constraints on the $\mathrm{Fe}(\mathrm{III}) / \mathrm{SO}_{4}$-reduction interface, Geochim. Cosmochim. Acta 60 (1996), pp. 3169-3175. 
Puziewicz et al., 2007 J. Puziewicz, K. Zainoun and H. Bril, Primary phases in pyrometallurgical slags from a Zn-smelting waste dump, Swietochlowice, Upper Silesia, Poland. Can. Mineral. 45 (2007), pp. 1189-1200.

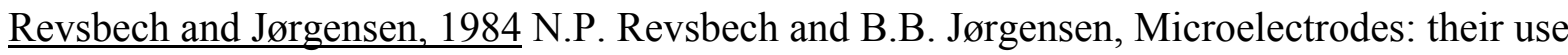
in microbial ecology. In: K.C. Marshall, Editor, Advances in Microbial Ecology, vol. 9, Plenum Publishing Co., New York (1984), pp. 293-352.

Ribet et al., 1995 I. Ribet, C.J. Ptacek, D.W. Blowes and J.L. Jambor, The potential for metal release by reductive dissolution of weathered mine tailings, J. Contam. Hydrol. 17 (1995), pp. 239-273.

Robert et al., 2004 S. Robert, G. Blanc, J. Schäfer, G. Lavaux and G. Abril, Metal mobilization in the Gironde Estuary (France): the role of the soft mud layer in the maximum turbidity zone, Mar. Chem. 87 (2004), pp. 1-13.

Romero et al., 2007 F.M. Romero, M.A. Armienta and G. Gonzalez-Hernandez, Solid-phase control on the mobility of potentially toxic elements in an abandoned lead/zinc mine tailings impoundment, Taxco, Mexico. Appl. Geochem. 22 (2007), pp. 109-127.

Roussel et al., 1999 C. Roussel, H. Bril and A. Fernandez, Evolution of sulphides-rich mine tailings and immobilization of As and Fe, C.R.A.S. Earth Planet. Sci. Series 329 (1999), pp. 787-794.

Salomons, 1995 W. Salomons, Environmental impact of metals derived from mining activities: Processes, predictions, Prev. J. Geochem. Explor. 52 (1995), pp. 5-23.

$\underline{\text { Samuel et al., } 1985}$ J. Samuel, R. Rouault and Y. Besnus, Analyse multiélémentaire standardisée des matériaux géologiques en spectrométrie d'émission par plasma à couplage inductif, Analusis 13 (1985), pp. 312-317.

Saulnier and Mucci, 2000 I. Saulnier and A. Mucci, Trace metal remobilization following the resuspension of estuarine sediments: Saguenay Fjord, Can. Appl. Geochem. 15 (2000), pp. $203-222$.

$\underline{\text { Schäfer et al., } 2006}$ J. Schäfer, G. Blanc, S. Audry, D. Cossa and C. Bossy, Mercury in the Lot-Garonne River system (France): Sources, fluxes and anthropogenic component, Appl. Geochem. 21 (2006), pp. 515-527.

Schäfer et al., 2002 J. Schäfer, G. Blanc, Y. Lapaquellerie, N. Maillet, E. Maneux and H. Etcheber, Ten-year observation of the Gironde tributary fluvial system: fluxes of suspended matter, particulate organic carbon and cadmium, Mar. Chem. 79 (2002), pp. 229-242.

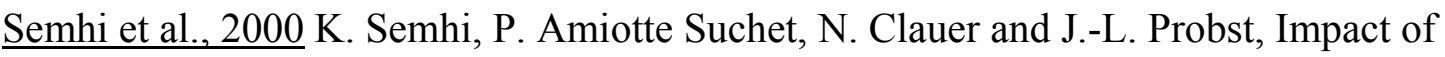
nitrogen fertilizers on the natural weathering-erosion processes and fluvial transport in the Garonne basin, Appl. Geochem. 15 (2000), pp. 865-878.

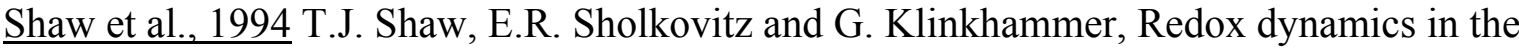
Chesapeake Bay: The effect on sediment/water uranium exchange, Geochim. Cosmochim. Acta 58 (1994), pp. 2985-2995. 
Sidenko and Sherriff, 2005 N.V. Sidenko and B.L. Sherriff, The attenuation of Ni, Zn and Cu, by secondary Fe phases of different crystallinity from surface and ground water of two sulfide mine tailings in Manitoba, Can. Appl. Geochem. 20 (2005), pp. 1180-1194.

Sidenko et al., 2001 N.V. Sidenko, R. Giere, S.B. Bortnikova, F. Cottard and N.A. Pal'chik, Mobility of heavy metals in self-burning waste heaps of the zinc smelting plant in Belovo (Kemerovo Region, Russia), J. Geochem. Explor. 74 (2001), pp. 109-125.

Simpson et al., 1998 S.L. Simpson, S.C. Apte and G.E. Batley, Effect of short-term resuspension events on trace metal speciation in polluted anoxic sediments, Environ. Sci. Technol. 32 (1998), pp. 620-625.

Simpson et al., 2000 S.L. Simpson, S.C. Apte and G.E. Batley, Effect of short-term resuspension events on the oxidation of cadmium, lead, and zinc sulfide phases in anoxic estuarine sediments, Environ. Sci. Technol. 34 (2000), pp. 4433-4537.

Soubrand-Colin et al., 2005 M. Soubrand-Colin, H. Bril, C. Neel, A. Courtin-Nomade and F. Martin, Weathering of basaltic rocks from the French Massif Central: origin and fate of $\mathrm{Ni}, \mathrm{Cr}$, $\mathrm{Zn}$ and $\mathrm{Cu}$, Can. Mineral. 43 (2005), pp. 1103-1118.

Spark et al., 1995 K.M. Spark, J.D. Wells and B.B. Johnson, Characterizing trace metal adsorption on kaolinite, Eur. J. Soil Sci. 46 (1995), pp. 633-640.

$\underline{\text { Suits and Arthur, } 2000}$ N.S. Suits and M.A. Arthur, Bacterial production of anomalously high dissolved sulfate concentrations in Peru slope sediments: steady-state sulfur oxidation, or transient response to end of El Nino?, Deep Sea Res. I: Oceanog. Res. Papers 47 (2000), pp. $1829-1853$.

Tack et al., 1996 F.M.G. Tack, H.A.H. Vossius and M.G. Verloo, A comparison between sediment metal fractions, obtained from sequential extraction and estimated from single extractions, Internat. J. Environ. Anal. Chem. 63 (1996), pp. 61-66.

Tack et al., 1999 F.M.G. Tack, H.A.H. Vossius and M.G. Verloo, Single extractions versus sequential extraction for the estimation of heavy metal fractions in reduced and oxidised dredged sediments, Chem. Speciat. Bioavailab. 11 (1999), pp. 43-50.

Tessier et al., 1979 A. Tessier, P.G.C. Campbell and M. Bisson, Sequential extraction procedure for the speciation of particulate trace metals, Environ. Sci. Technol. 51 (1979), pp. $844-851$.

Tessier et al., 1996 A. Tessier, D. Fortin, N. Belzile, R.R. DeVitre and G.G. Leppard, Metal sorption to diagenetic iron and manganese oxyhydroxides and associated organic matter: narrowing the gap between field and laboratory measurements, Geochim. Cosmochim. Acta 60 (1996), pp. 387-404.

Thiry et al., 2002 M. Thiry, S. Huet-Taillander and J.M. Schmitt, The industrial waste land of Mortagne-du-Nord (59) - I - assessment, composition of the slags hydrochemistry, hydrology and the estimate of the outfluxes, Bull. Soc. Geol. France 173 (2002), pp. 369-381 
van den Berg et al., 1999 G.A. van den Berg, J.P.G. Loch, L.M. Van Der Heijdt and J.J.G. Zwolsman, Mobilisation of heavy metals in contaminated sediments in the river Meuse, The Netherlands, Water, Air, Soil Pollut. 116 (1999), pp. 567-586.

Widerlund, 1996 A. Widerlund, Early diagenetic remobilization of copper in near-shore marine sediments: a quantitative pore-water model, Mar. Chem. 54 (1996), pp. 41-53.

Widerlund et al., 2005 A. Widerlund, E. Shcherbakova, E. Carlsson, H. Holmstrom and B. Ohlander, Laboratory study of calcite-gypsum sludge-water interactions in a flooded tailings impoundment at the Kristineberg Zn-Cu mine, northern Sweden, Appl. Geochem. 20 (2005), pp. 973-987.

Zaggia and Zonta, 1997 L. Zaggia and R. Zonta, Metal-sulphide formation in the contaminated anoxic sludge of the Venice canals, Appl. Geochem. 12 (1997), pp. 527-536. 
Figures and Tables

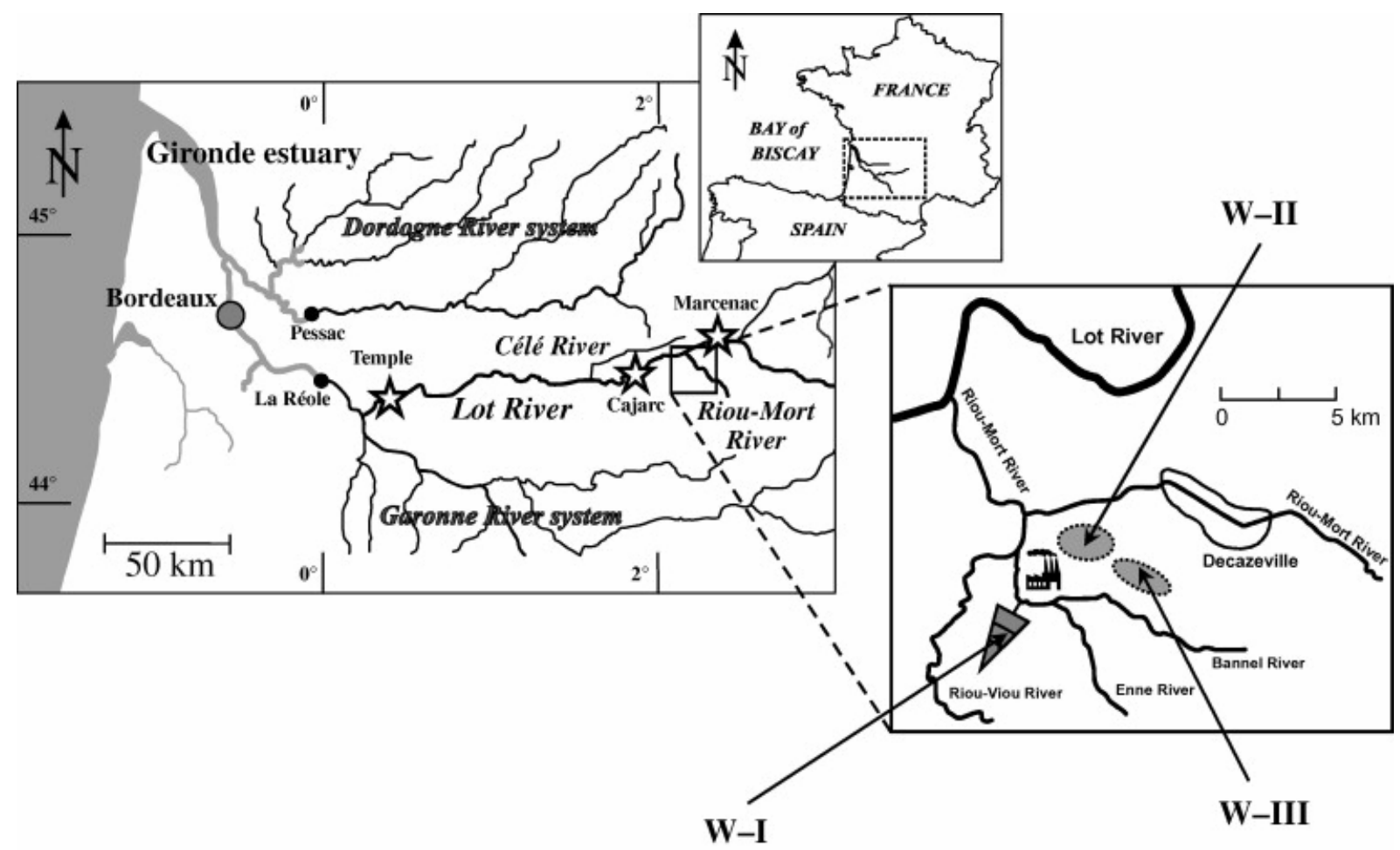

Fig. 1. Map of the study area and location of the sampling sites (Marcenac, Cajarc, Temple) shown as open stars. 
Table 1. Operating conditions applied for the selective extraction procedures.

\begin{tabular}{|c|c|c|c|c|}
\hline Fraction & $\begin{array}{l}\text { Sample } \\
\text { weight (mg) }\end{array}$ & Reagents & $\begin{array}{l}\text { Shaking time, } \\
\text { temperature }\end{array}$ & References \\
\hline \multirow[t]{2}{*}{ - F1 - exchangeable/carbonate } & 500 & $\begin{array}{l}10 \mathrm{~mL} \mathrm{NaOAc} 1 \mathrm{M}+\mathrm{HOAc} \\
(\mathrm{pH}=5)\end{array}$ & $5 \mathrm{~h}$ at $25^{\circ} \mathrm{C}$ & $\frac{\text { Tessier et al. }}{(1979)}$ \\
\hline & & $\begin{array}{l}\mathrm{pH} \text { adjustment with } \mathrm{HOAc} \\
5 \mathrm{M} \text { during the extraction }\end{array}$ & & \\
\hline $\begin{array}{l}\text { - } \mathrm{F} 2-\mathrm{Fe} / \mathrm{Mn} \text {-oxides } \\
\text { (reducible) }\end{array}$ & 200 & $\begin{array}{l}12.5 \mathrm{~mL} \text { ascorbate solution } \\
(\mathrm{pH}=8)\end{array}$ & $24 \mathrm{~h}$ at $25^{\circ} \mathrm{C}$ & $\begin{array}{l}\text { Kostka and Luther } \\
\underline{(1994)}\end{array}$ \\
\hline \multirow[t]{3}{*}{$\begin{array}{l}\text { - F3 - organic matter/sulfides } \\
\text { (oxidizable) }\end{array}$} & 1000 & $\begin{array}{l}8 \mathrm{ml} \mathrm{H}_{2} \mathrm{O}_{2} 30 \% \mathrm{~m} / \mathrm{v}+\mathrm{NaOH} \\
(\mathrm{pH}=5)\end{array}$ & $2 \mathrm{~h}$ at $85^{\circ} \mathrm{C}$ & $\begin{array}{l}\text { Tessier et al. } \\
(1979) \text { modified }\end{array}$ \\
\hline & & $\begin{array}{l}\text { then } 3 \mathrm{~mL} \mathrm{H}_{2} \mathrm{O}_{2} 30 \% \\
\mathrm{~m} / \mathrm{v}+\mathrm{NaOH}\end{array}$ & $2 \mathrm{~h}$ at $85^{\circ} \mathrm{C}$ & $\begin{array}{l}\text { by } \underline{\text { Ma and Uren }} \\
(1995)\end{array}$ \\
\hline & & $\begin{array}{l}\text { then } 5 \mathrm{~mL} \mathrm{NH}_{4} \mathrm{OAc} \\
1 \mathrm{M}+20 \mathrm{~mL} \mathrm{H}_{2} \mathrm{O} \text { milli-Q }\end{array}$ & 30 min. at $25^{\circ} \mathrm{C}$ & \\
\hline - TMC - total metal content & 30 & $\begin{array}{l}\mathrm{HCl} 12 \mathrm{~N}+\mathrm{HNO}_{3} 14 \mathrm{~N}+\mathrm{HF} \\
26 \mathrm{~N}\end{array}$ & $2 \mathrm{~h}$ at $110^{\circ} \mathrm{C}$ & $\frac{\text { Schafer et al. }}{(2002)}$ \\
\hline
\end{tabular}

Table 2. Bulk composition ( $\mathrm{mg} \mathrm{kg}^{-1}$ ) of selected samples from the waste areas.

\begin{tabular}{|l|l|l|l|l|l|l|l|l|l|l|l|}
\hline & Na & Mg & K & Ca & Mn & Fe & Cu & Zn & As & Cd & Pb \\
\hline W-I & 164 & 249 & 1120 & 9140 & 1004 & 67770 & 1380 & 16790 & 1140 & 67 & 3470 \\
\hline W-II & 451 & 581 & 3190 & 30780 & 489 & 22570 & 667 & 11830 & 2150 & 52 & 8750 \\
\hline W-III & 462 & 2870 & 1280 & 9550 & 561 & 12850 & 1670 & 20810 & 180 & 103 & 2520 \\
\hline
\end{tabular}



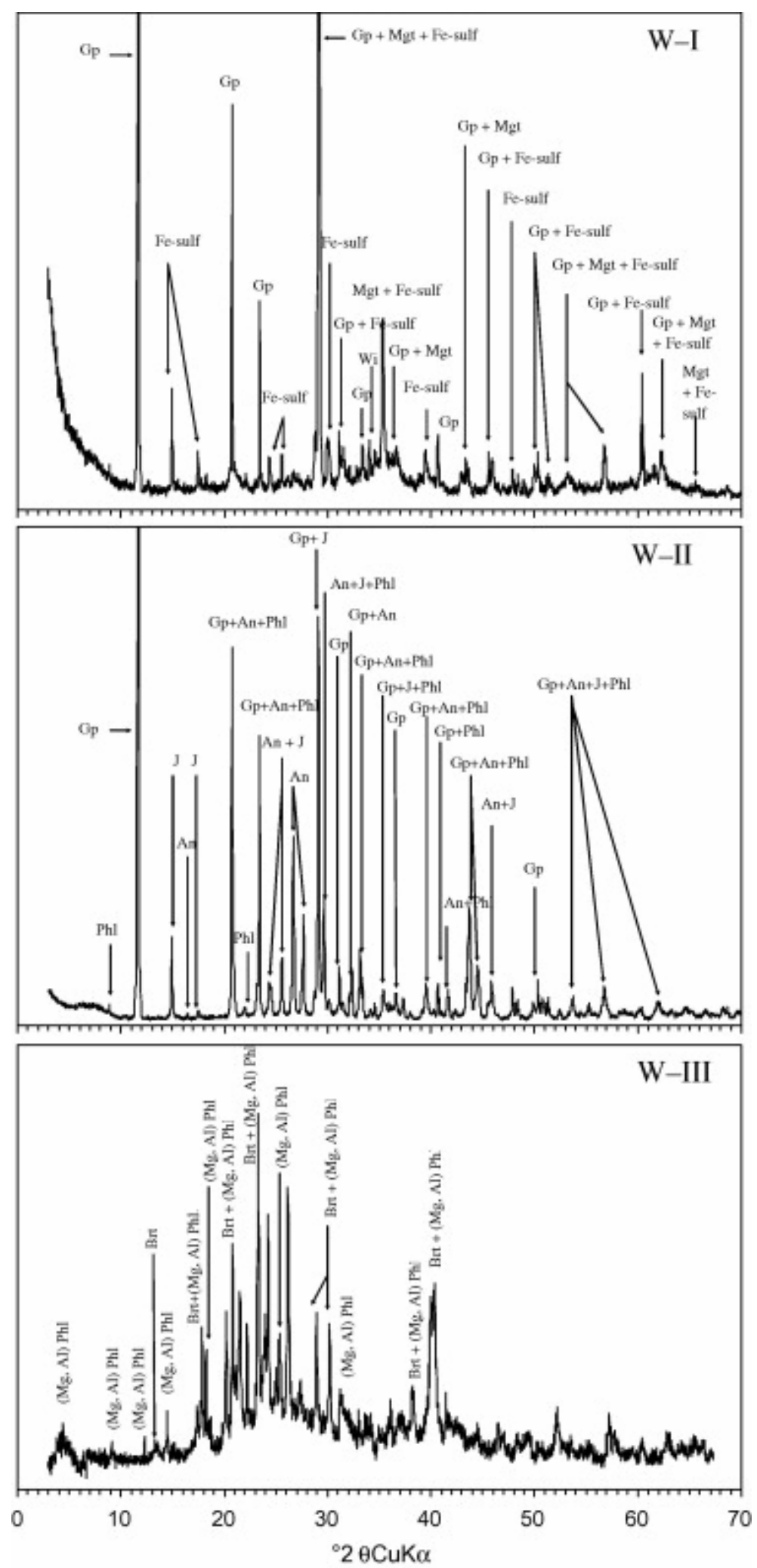

Fig. 2. XRD patterns of representative samples from the smelting waste areas (W-I, W-II, $\mathrm{W}-\mathrm{III}$ ) located in the Riou Mort River watershed. Abbreviations: $\mathrm{An}=$ anglesite; $\mathrm{Brt}=$ Barite; Fe-sulf = Fe-oxyhydroxysulfate; $\mathrm{Gp}=$ gypsum; $\mathrm{J}=$ Jarosite; Mgt = Magnetite;

$\mathrm{Phl}=$ Phyllosilicates; $\mathrm{Sp}=$ sphalerite $; \mathrm{Wi}=$ willemite . 
Smelting area
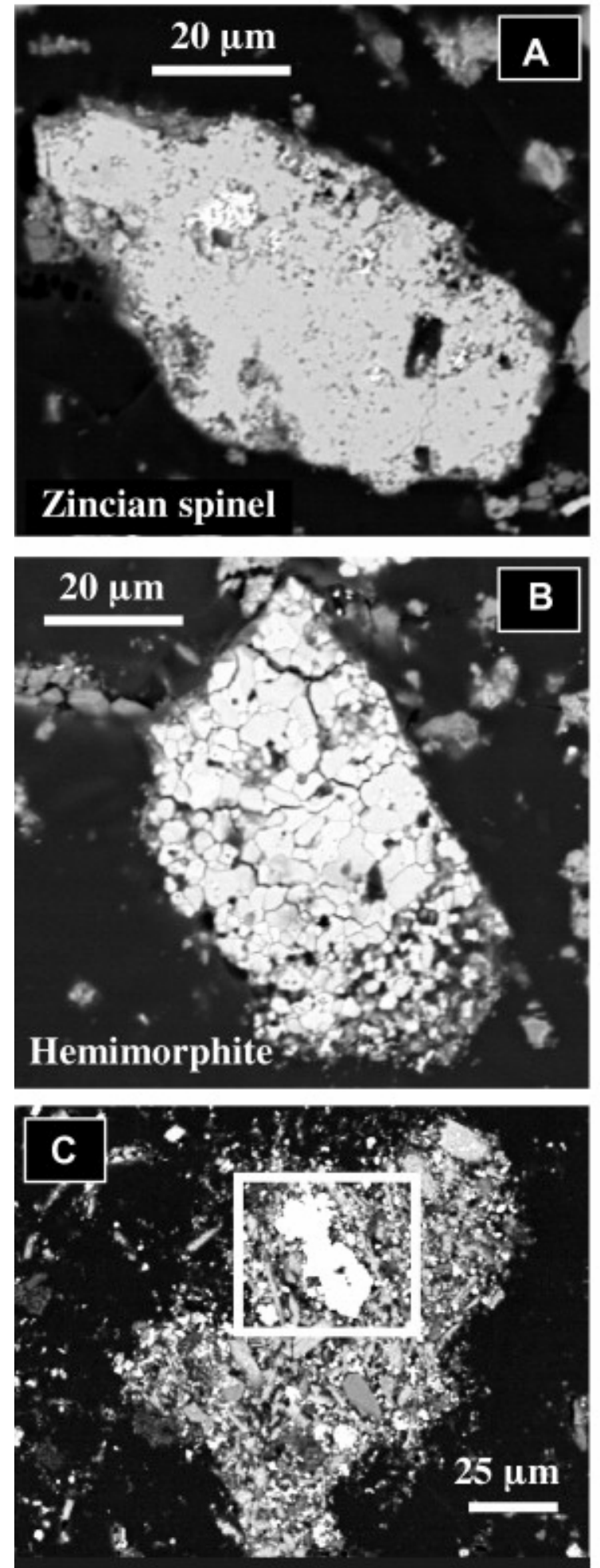

$(\mathrm{Pb}, \mathrm{Ba})$ sulfate solid solution
Reservoir sediments
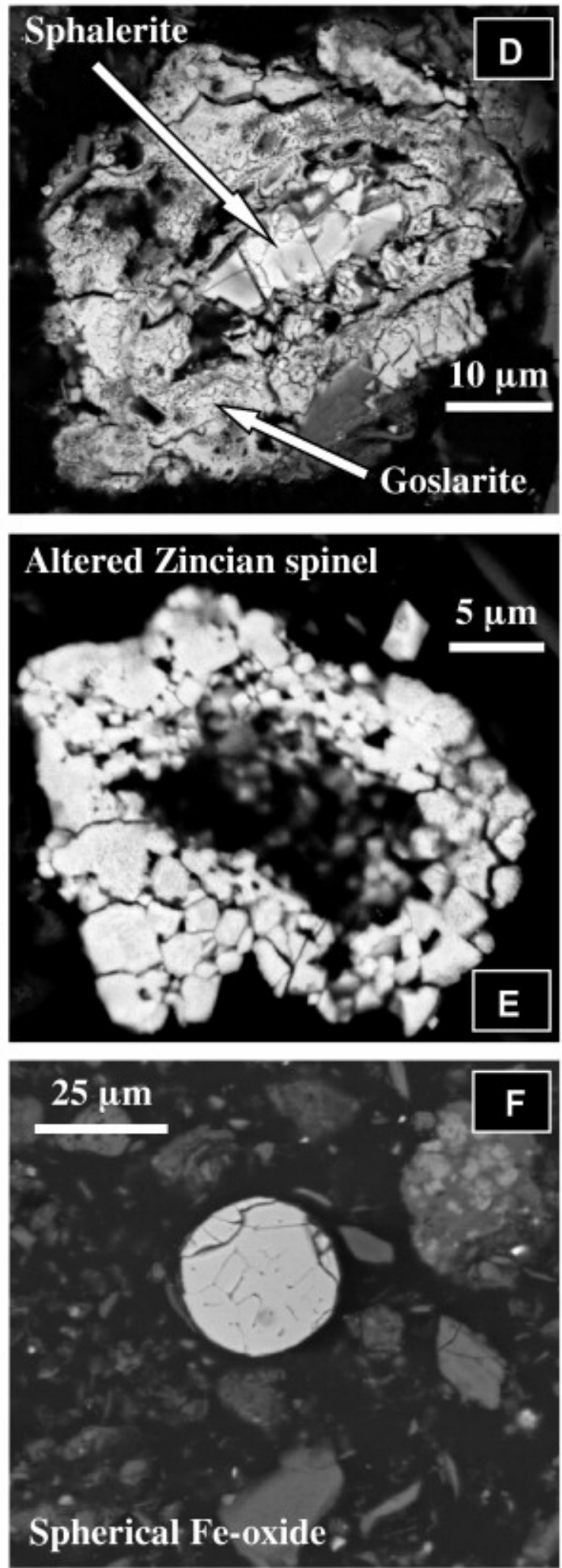

Fig. 3. BSE microscope images of representative trace metal-bearing phases from the smelting areas in the Riou Mort watershed (A, B, C) and in the reservoir sediments of Cajarc (D, E, F). Image D shows the hydration of sphalerite in the center to a phase approximating the composition of goslarite on the edge. 
Table 3. Representative EMPA compositions (wt.\%) of the major trace metal-bearing phases in the smelting areas and in the reservoir sediments. Amounts of $\mathrm{Fe}^{2+}$ and $\mathrm{Fe}^{3+}$ in the formula of spinel-group phases were calculated by charge-balance.

\begin{tabular}{|c|c|c|c|c|c|c|c|c|c|c|c|}
\hline & \multicolumn{4}{|c|}{ Smelting area } & & \multicolumn{6}{|c|}{ Reservoir sediments } \\
\hline & $\begin{array}{l}\text { Anglesit } \\
\text { e-barite } \\
\text { solid } \\
\text { solution } \\
\underline{a}\end{array}$ & $\begin{array}{l}\text { Angl } \\
\text { e-site }\end{array}$ & 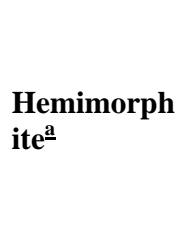 & $\begin{array}{l}\text { Zincian } \\
\text { spinel }^{\mathbf{a}} \\
\text { (Franklini } \\
\text { te-type) }\end{array}$ & & $\begin{array}{l}\text { Alter } \\
\text { ed } \\
\text { zincia } \\
\mathbf{n} \\
\text { spinel } \\
\underline{\mathbf{a}}\end{array}$ & $\begin{array}{l}\text { Goslarit } \\
\mathrm{e}^{\underline{\mathbf{a}}}\end{array}$ & $\begin{array}{l}\text { Spheric } \\
\text { al Fe } \\
\text { oxide }^{\underline{a}}\end{array}$ & $\begin{array}{l}\text { Fe } \\
\text { oxyhyd } \\
\text { r-oxide }\end{array}$ & & $\begin{array}{l}\text { Sphaleri } \\
\text { te }^{\underline{\underline{a}}}\end{array}$ \\
\hline $\mathrm{ZnO}$ & - & 1.5 & 58.2 & 31.3 & $\mathrm{ZnO}$ & 20.4 & 28.1 & 0.7 & 2.1 & $\begin{array}{l}\mathrm{Z} \\
\mathrm{n}\end{array}$ & 65.0 \\
\hline $\mathrm{SiO}_{2}$ & 0.2 & 0.7 & 22.8 & - & $\mathrm{SiO}_{2}$ & 1.5 & 2.4 & - & 2 & & \\
\hline $\mathrm{FeO}$ & - & 0.3 & 5.2 & 0.1 & $\mathrm{FeO}$ & 5.6 & 0.4 & - & 82.5 & $\begin{array}{l}\mathrm{F} \\
\mathrm{e}\end{array}$ & 0.5 \\
\hline $\begin{array}{l}\mathrm{Fe}_{2} \mathrm{O} \\
3\end{array}$ & - & - & - & 64.8 & $\begin{array}{l}\mathrm{Fe}_{2} \mathrm{O} \\
3\end{array}$ & 44.3 & - & 96.5 & - & & \\
\hline $\begin{array}{l}\mathrm{Al}_{2} \mathrm{O} \\
3\end{array}$ & 0.1 & 0.2 & 0.6 & 0.1 & $\begin{array}{l}\mathrm{Al}_{2} \mathrm{O} \\
3\end{array}$ & 0.6 & 0.5 & - & 0.7 & & \\
\hline $\mathrm{PbO}$ & 41.8 & 66 & - & 0.4 & $\mathrm{PbO}$ & 0.7 & - & 0.4 & 0.3 & & \\
\hline $\mathrm{BaO}$ & 22.4 & 8 & 0.3 & 0.1 & $\mathrm{BaO}$ & 0.6 & - & - & 0.1 & & \\
\hline $\mathrm{SO}_{3}$ & 29.9 & 23.7 & 0.3 & - & $\mathrm{SO}_{3}$ & - & 21.9 & - & 0.2 & $\mathrm{~S}$ & 33.0 \\
\hline $\mathrm{CaO}$ & 1.5 & 0.5 & 0.2 & 0.1 & $\mathrm{CaO}$ & 0.2 & 0.9 & 0.2 & 0.1 & & \\
\hline $\begin{array}{l}\mathrm{Na}_{2} \\
\mathrm{O}\end{array}$ & - & - & 1.4 & 0.9 & $\begin{array}{l}\mathrm{Na}_{2} \\
\mathrm{O}\end{array}$ & 0.7 & 0.6 & - & 0.2 & & \\
\hline $\mathrm{K}_{2} \mathrm{O}$ & - & - & - & - & $\mathrm{K}_{2} \mathrm{O}$ & 0.2 & 0.1 & - & - & & \\
\hline $\begin{array}{l}\mathrm{Mg} \\
\mathrm{O}\end{array}$ & - & - & 1.3 & 0.5 & $\begin{array}{l}\mathrm{Mg} \\
\mathrm{O}\end{array}$ & - & 0.1 & - & 0.2 & & \\
\hline $\mathrm{TiO}_{2}$ & - & - & 2.2 & - & $\mathrm{TiO}_{2}$ & - & 0.1 & 0.1 & - & & \\
\hline $\begin{array}{l}\mathrm{Mn} \\
\mathrm{O}\end{array}$ & - & - & 0.1 & 0.7 & $\begin{array}{l}\mathrm{Mn} \\
\mathrm{O}\end{array}$ & 0.2 & - & 0.6 & 0.3 & & \\
\hline $\mathrm{CdO}$ & - & - & - & 0.1 & $\mathrm{CdO}$ & 0.7 & - & 0.94 & - & & \\
\hline $\mathrm{P}_{2} \mathrm{O}_{5}$ & - & - & - & - & $\mathrm{P}_{2} \mathrm{O}_{5}$ & - & 2.8 & - & 0.16 & & \\
\hline $\begin{array}{l}\mathrm{As}_{2} \\
\mathrm{O}_{3}\end{array}$ & - & - & - & - & $\begin{array}{l}\mathrm{As}_{2} \\
\mathrm{O}_{3}\end{array}$ & - & 0.2 & - & 0.16 & & \\
\hline $\mathrm{CuO}$ & - & - & 0.4 & 0.3 & $\mathrm{CuO}$ & 0.5 & - & - & 0.41 & & \\
\hline $\begin{array}{l}\text { Tota } \\
1\end{array}$ & 96.2 & 100.9 & 93.2 & 99.6 & $\begin{array}{l}\text { Tota } \\
1\end{array}$ & 76.3 & 58 & 99.5 & 89.4 & & 98.6 \\
\hline
\end{tabular}

-: Under detection limit.

${ }^{a}$ Phase shown in Fig. 3. 
Table 4. Mean \pm standard deviation of major element (wt.\%), particulate organic carbon (POC;\%) and total sulfur (Stot;\%) concentrations of the sediment cores.

\begin{tabular}{|l|l|l|l|}
\hline & Marcenac & Cajarc & Temple \\
\hline & $(\boldsymbol{n}=44)$ & $(\boldsymbol{n}=35)$ & $(\boldsymbol{n}=\mathbf{2 2})$ \\
\hline $\mathrm{SiO}_{2}$ & $64.1 \pm 7.6$ & $57.1 \pm 5.7$ & $63.4 \pm 7.8$ \\
\hline $\mathrm{A}_{2} \mathrm{O}_{3}$ & $12.8 \pm 2.5$ & $14.9 \pm 1.8$ & $12.2 \pm 1.8$ \\
\hline $\mathrm{MgO}$ & $1.3 \pm 0.3$ & $1.4 \pm 0.2$ & $1.4 \pm 0.4$ \\
\hline $\mathrm{CaO}$ & $1.8 \pm 0.6$ & $1.4 \pm 0.2$ & $3.6 \pm 1.2$ \\
\hline $\mathrm{Fe}_{2} \mathrm{O}_{3}$ & $4.1 \pm 1.1$ & $6.2 \pm 1.3$ & $4.6 \pm 1.2$ \\
\hline $\mathrm{MnO}$ & $0.09 \pm 0.04$ & $0.16 \pm 0.06$ & $0.09 \pm 0.04$ \\
\hline $\mathrm{TiO}_{2}$ & $0.70 \pm 0.08$ & $0.66 \pm 0.06$ & $0.70 \pm 0.11$ \\
\hline $\mathrm{Na}_{2} \mathrm{O}$ & $1.4 \pm 0.2$ & $1.1 \pm 0.2$ & $1.1 \pm 0.2$ \\
\hline $\mathrm{K}_{2} \mathrm{O}$ & $2.8 \pm 0.4$ & $3.0 \pm 0.3$ & $2.7 \pm 0.2$ \\
\hline $\mathrm{P}_{2} \mathrm{O}_{5}$ & $0.20 \pm 0.06$ & $0.22 \pm 0.07$ & $0.22 \pm 0.08$ \\
\hline $\mathrm{POC}$ & $4.2 \pm 2.0$ & $5.2 \pm 1.9$ & $3.4 \pm 2.0$ \\
\hline $\mathrm{Stot}$ & $0.08 \pm 0.03$ & $0.33 \pm 0.11$ & $0.13 \pm 0.06$ \\
\hline
\end{tabular}


a

(•) $\mathrm{SiO}_{2}(\mathrm{wt} . \%)$

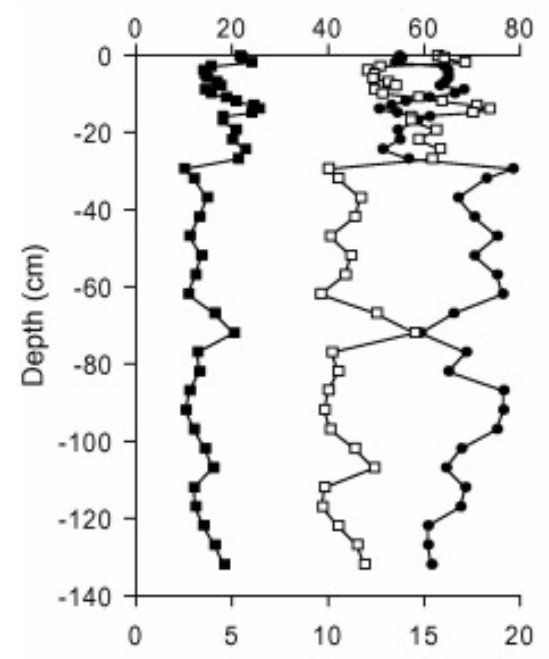

() $\mathrm{Al}_{2} \mathrm{O}_{3}$ (wt.\%), (घ) $\mathrm{Fe}_{2} \mathrm{O}_{3}$ (wt.\%) b

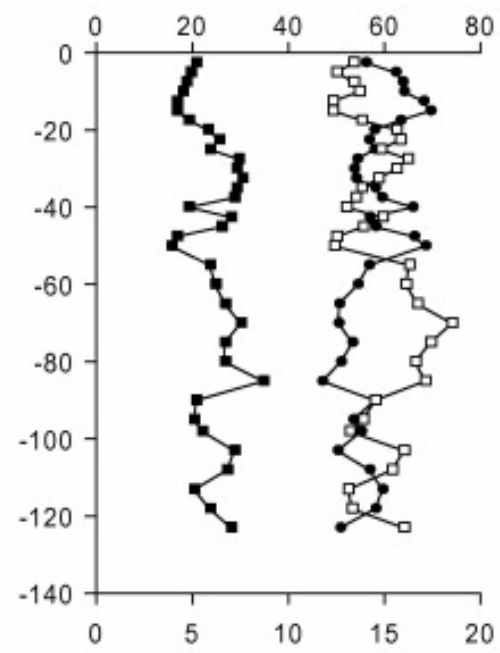

(ㅁ) $\mathrm{Al}_{2} \mathrm{O}_{3}$ (wt.\%), (-) $\mathrm{Fe}_{2} \mathrm{O}_{3}$ (wt.\%)
C

(•) $\mathrm{SiO}_{2}(w t . \%)$

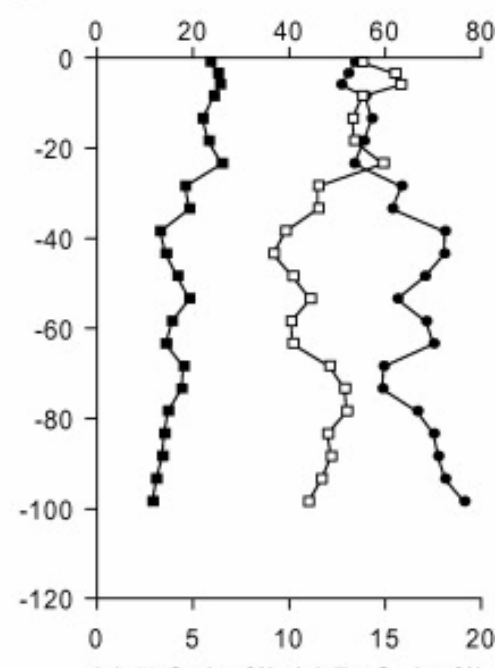

() $\mathrm{Al}_{2} \mathrm{O}_{3}$ (wt.\%), (-) $\mathrm{Fe}_{2} \mathrm{O}_{3}$ (wt.\%)

Fig. 4. Concentration (wt.\%) vs. depth profiles for $\mathrm{SiO}_{2}, \mathrm{Al}_{2} \mathrm{O}_{3}$ and $\mathrm{Fe}_{2} \mathrm{O}_{3}$ in Marcenac (a), Cajarc (b) and Temple (c) sediments. 
(ㅁ) $\mathrm{NH}_{4}{ }^{+}(\mu \mathrm{M})$

(o) $\mathrm{SO}_{4}{ }^{2-}(\mu \mathrm{M})$

(o) $\mathrm{Mn}(\mathrm{mM})$

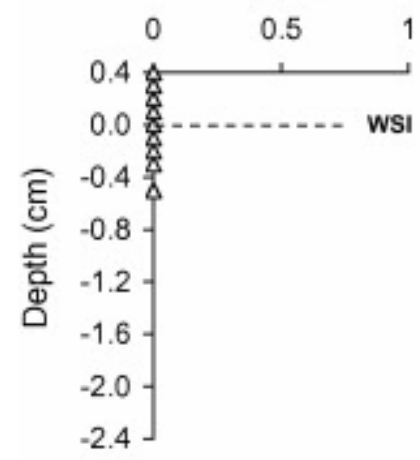

b $\mathrm{O}_{2}(\%)$

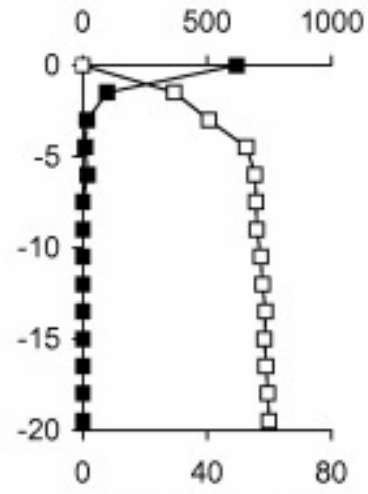

(a) $\mathrm{NO}_{3}{ }^{-}(\mu \mathrm{M})$
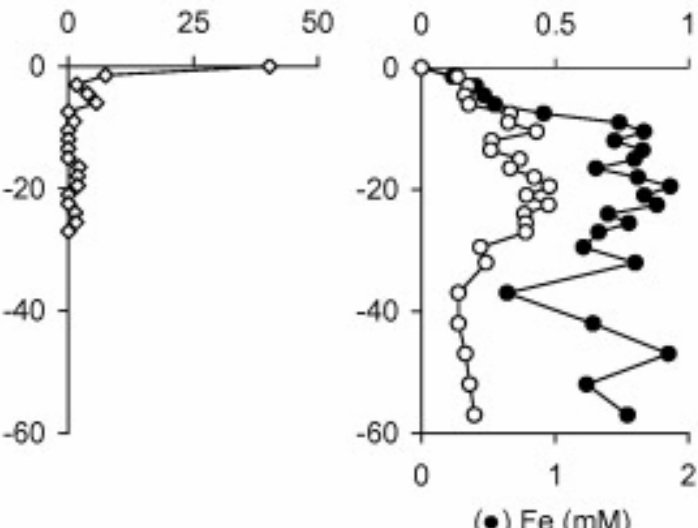

(ㅁ) $\mathrm{NH}_{4}{ }^{+}(\mu \mathrm{M})$

(०) $\mathrm{SO}_{4}{ }^{2-}(\mu \mathrm{M})$

(o) $\mathrm{Mn}(\mathrm{mM})$
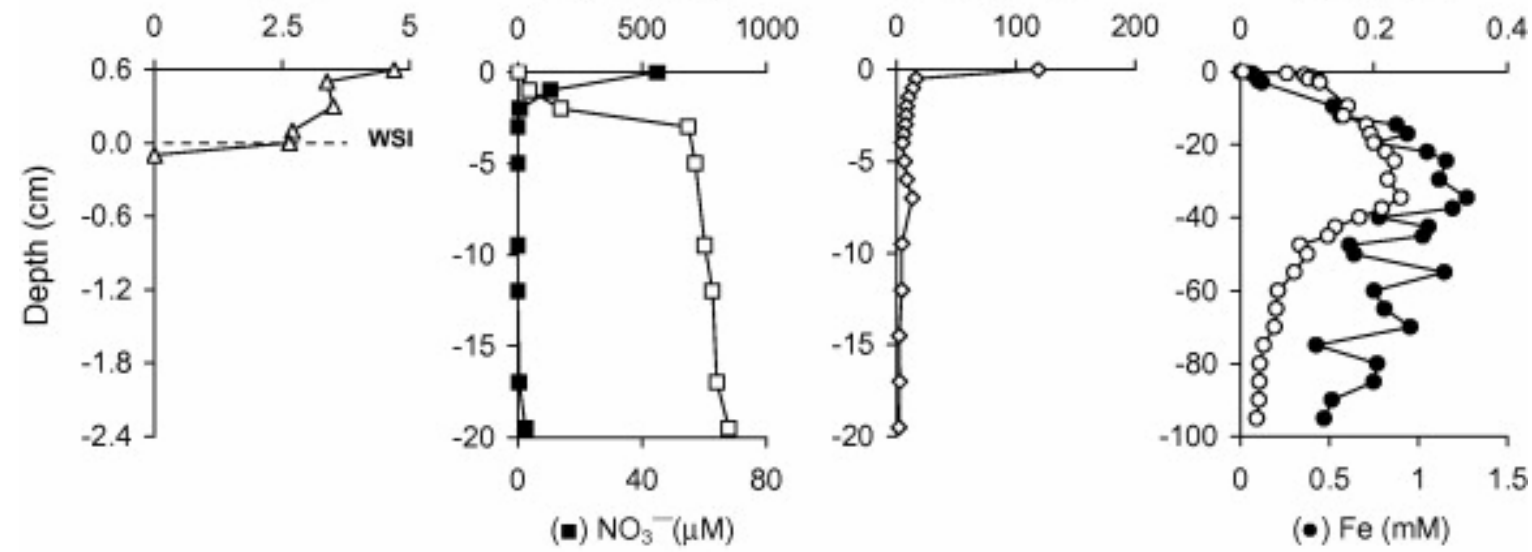

C $\mathrm{O}_{2}(\%)$

() $\mathrm{NH}_{4}{ }^{+}(\mu \mathrm{M})$

(०) $\mathrm{SO}_{4}{ }^{2-}(\mu \mathrm{M})$

(•) $\mathrm{Fe}(\mathrm{mM})$
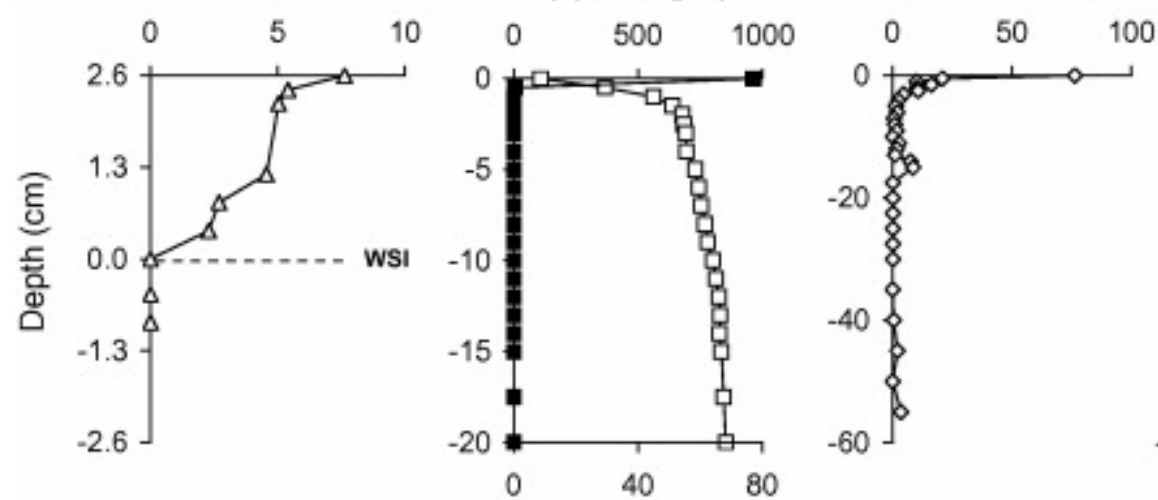

(a) $\mathrm{NO}_{3}{ }^{-}(\mu \mathrm{M})$

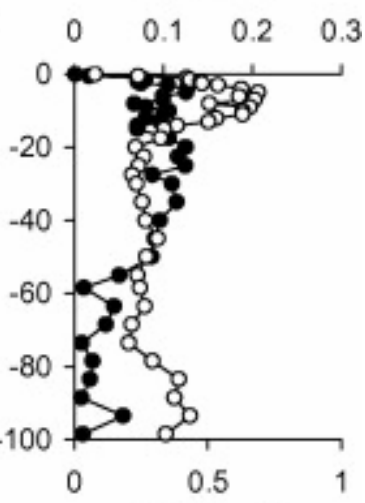

(•) $\mathrm{Fe}(\mathrm{mM})$

Fig. 5. Concentration-depth profiles for $\mathrm{O}_{2}, \mathrm{~N}$-species, $\mathrm{SO}_{4}, \mathrm{Fe}$ and $\mathrm{Mn}$ in the pore water of the cores from Marcenac (a), Cajarc (b) and Temple (c). Note that for data presentation convenience, the vertical scale on each panel is different. 'Zero' on the vertical scale represents the water-sediment interface (WSI) with positive depth referring to the water column and negative depth to the sediment. 

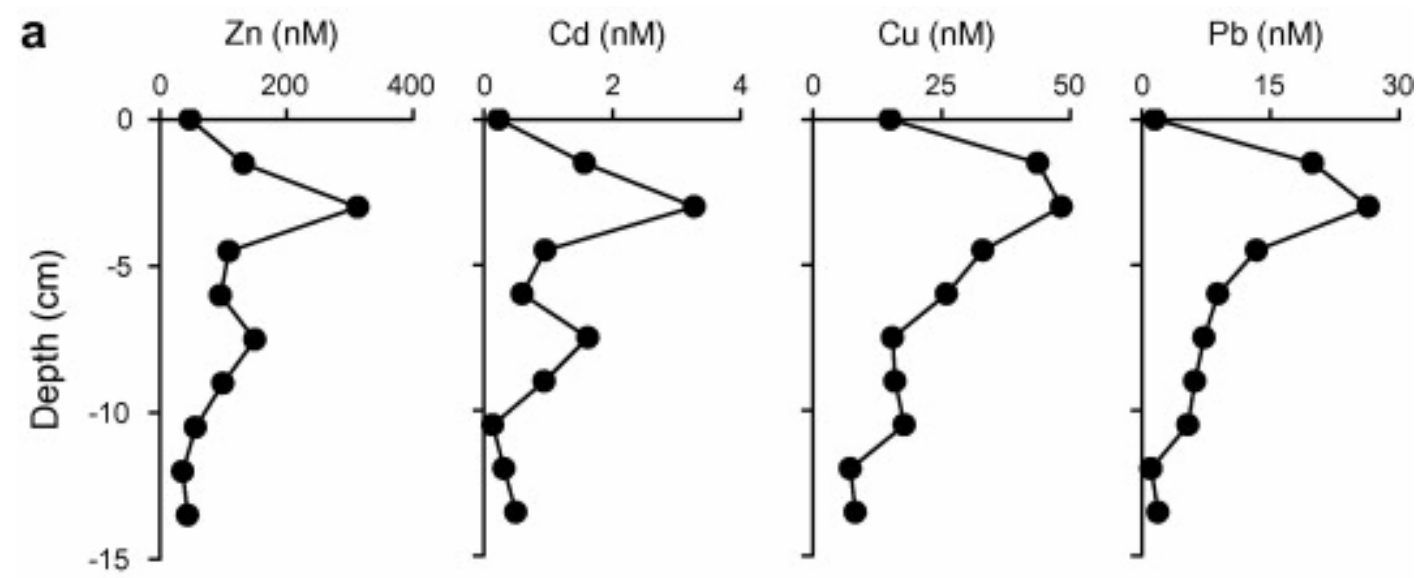

b
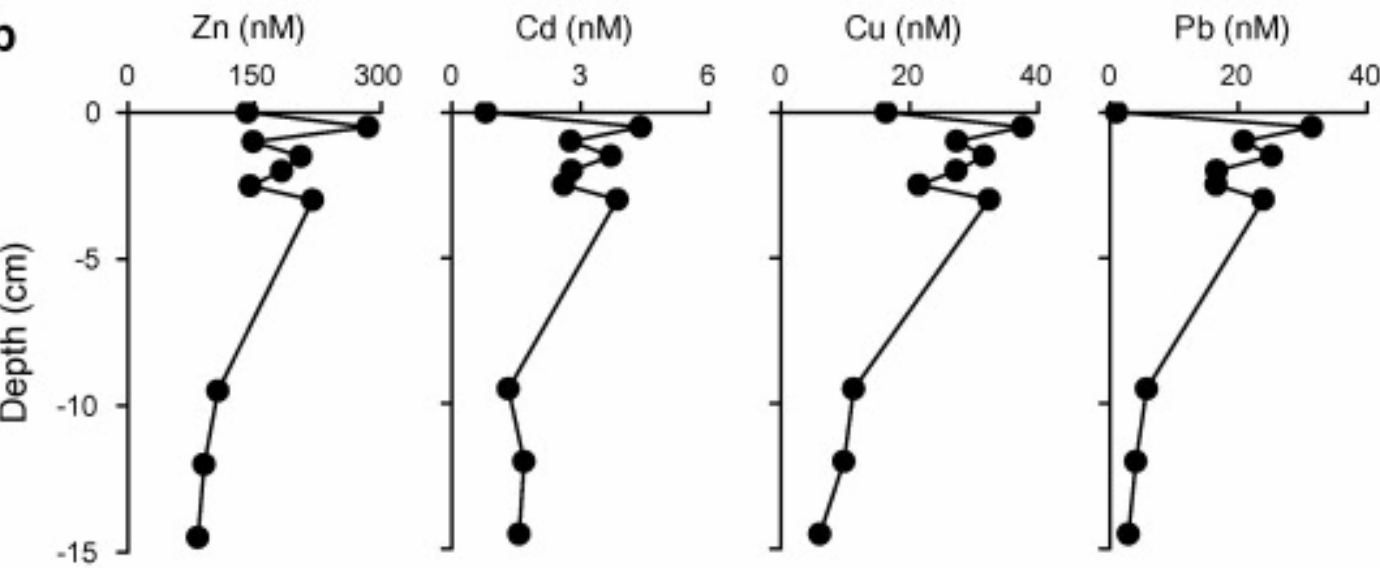

C

$\mathrm{Zn}(\mathrm{nM})$

Cd (nM)

$\mathrm{Cu}(\mathrm{nM})$

$\mathrm{Pb}(\mathrm{nM})$
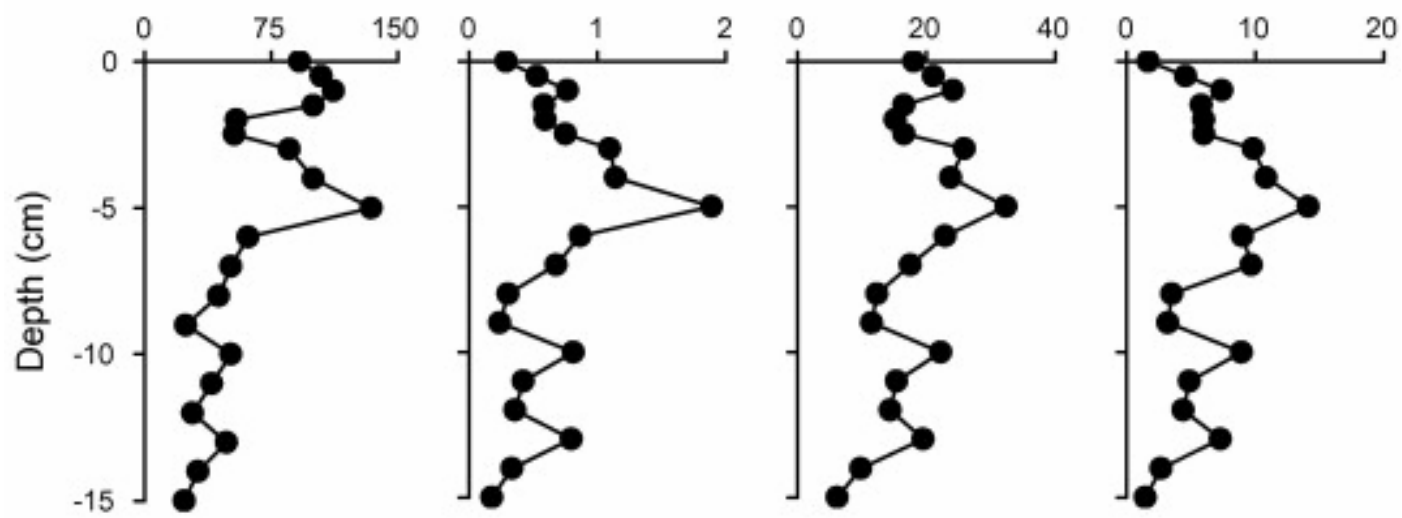

Fig. 6. Concentration-depth profiles of dissolved trace metals in the first $15 \mathrm{~cm}$ of the cores from Marcenac (a), Cajarc (b), and Temple (c). 

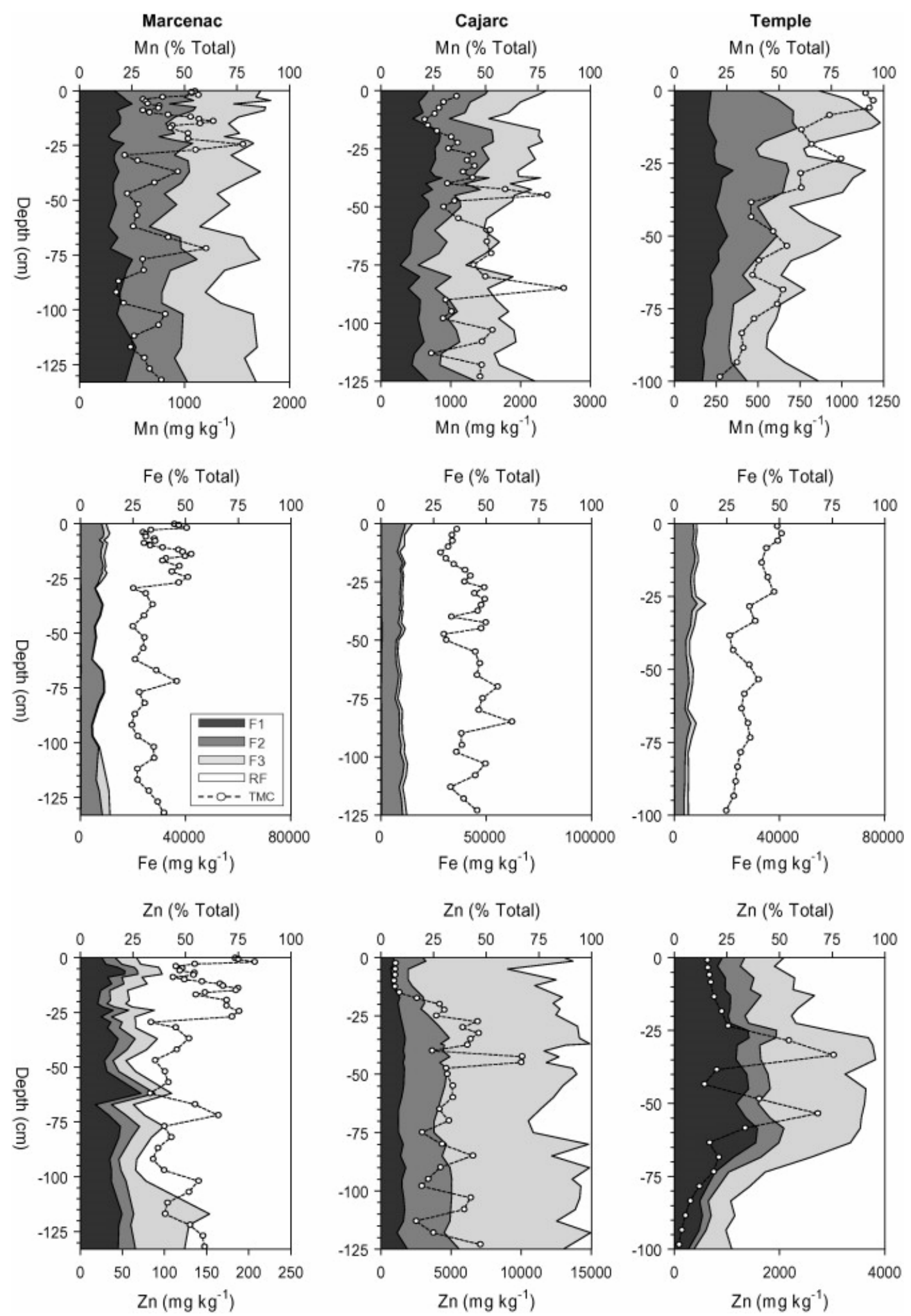

Fig. 7. Chemical partitioning of $\mathrm{Mn}, \mathrm{Fe}$ and $\mathrm{Zn}$, expressed as $\%$ of the total metal content (TMC), in the three sediment cores. Note that the scales for total concentrations of trace metals are adapted to the concentration ranges, covering different orders of magnitude. F1: exchangeable/carbonate; F2: Fe/Mn-oxides; F3: organic matter/sulfides, RF: residual. 

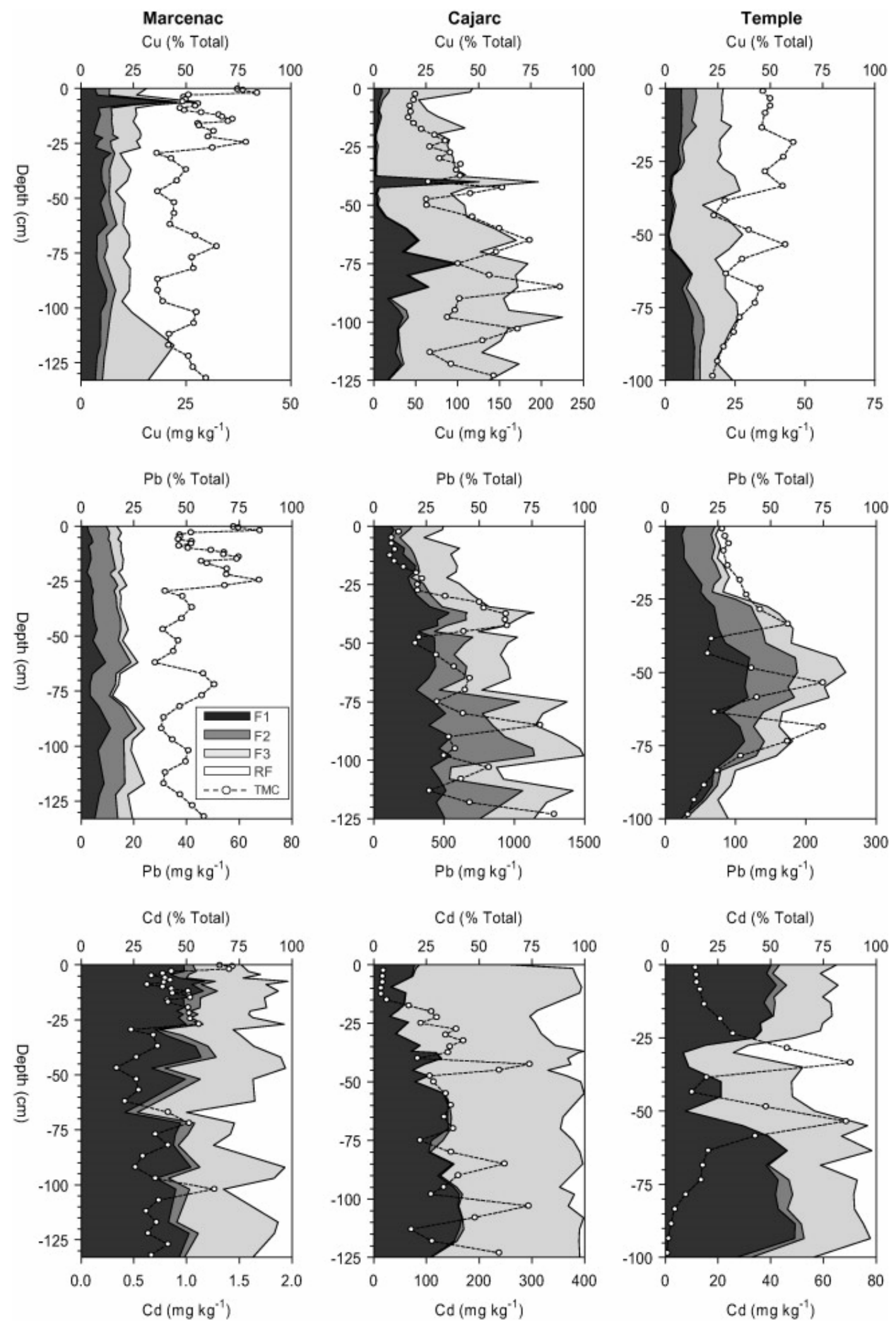

Fig. 8. Chemical partitioning of $\mathrm{Cu}, \mathrm{Pb}$ and $\mathrm{Cd}$, expressed as $\%$ of the total metal content (TMC), in the three sediment cores. Note that the scales for total concentrations of trace metals are adapted to the concentration ranges, covering different orders of magnitude. F1: exchangeable/carbonate; F2: Fe/Mn-oxides; F3: organic matter/sulfides, RF: residual. 
a
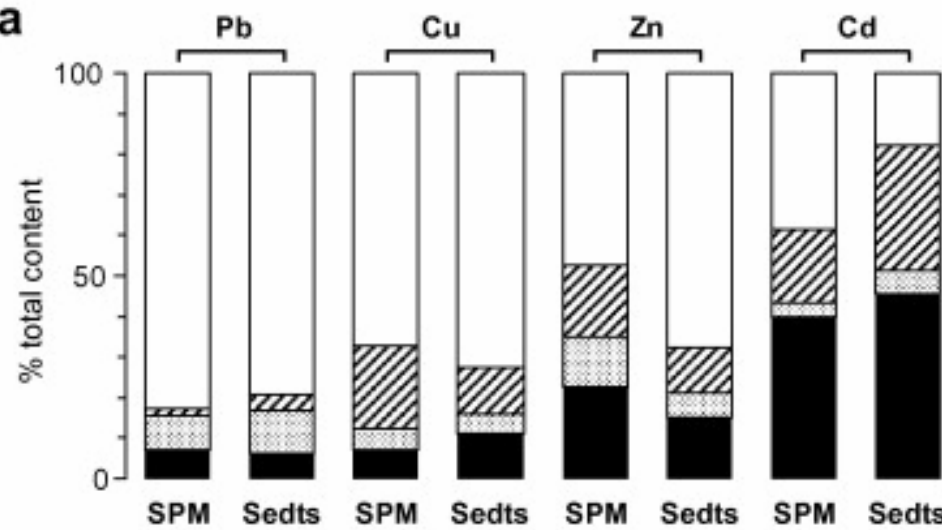

SPM Sedts

SPM Sedts

b

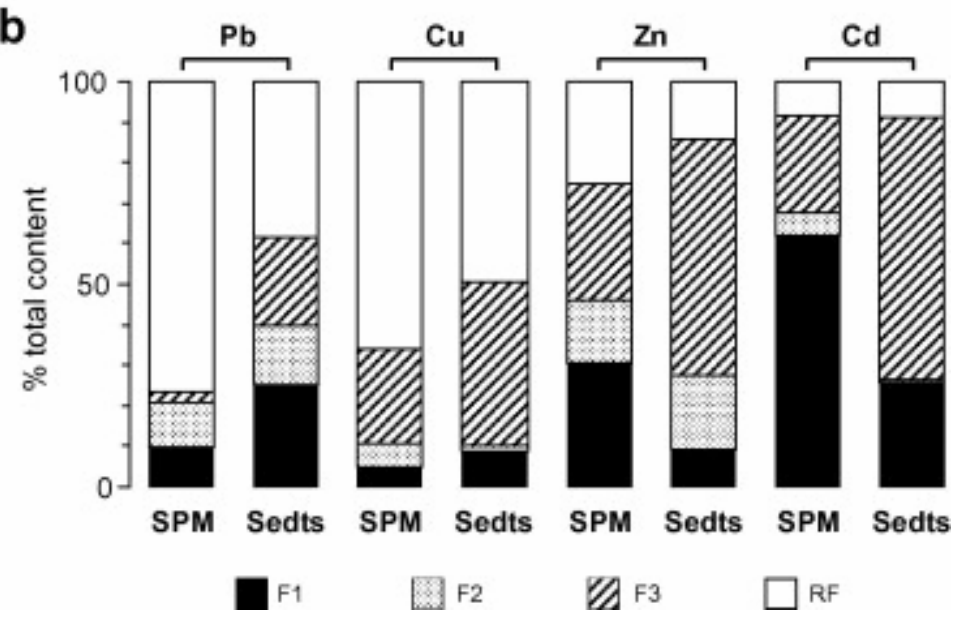

Fig. 9. Comparison between the chemical partitioning of trace metals in suspended particulate matter (SPM) and sediments (sedts) in the Marcenac (a) and Cajarc (b) sites. Trace metal partitioning in SPM and sediments is similar at the Marcenac site, suggesting low postdepositional redistribution of trace metals. In contrast, trace metal partitioning in SPM and sediments significantly differ at the Cajarc site, showing an increased contribution of the oxidizable fraction (F3) in the sediments and therefore suggesting high post-depositional redistribution of trace metals due to early diagenetic processes (see text for details). F1: exchangeable/carbonate; F2: Fe/Mn-oxides; F3: organic matter/sulfides, RF: residual. 
Table 5. Potential release of trace metal into the water column in Cajarc and Temple reservoirs from sulfide phase oxidation following two sediment-resuspension scenarios (see text for details). All figures are expressed in tons.

\begin{tabular}{|l|l|l|l|l|l|}
\hline & & Cd & Zn & Cu & Pb \\
\hline Trace metal inventory ${ }^{\mathrm{a}}$ & Cajarc & 23.1 & $1090 \pm 138$ & $111 \pm 45$ & $25.4 \pm 18.5$ \\
\hline & Temple & 55 & $2750 \pm 385$ & $264 \pm 116$ & $99 \pm 49$ \\
\hline 50 cm depth resuspension $^{-}$ & Cajarc & 6.3 & $269 \pm 48$ & $4 \pm 4$ & $10 \pm 6$ \\
\hline & Temple & 11.3 & $599 \pm 119$ & $13 \pm 9$ & $15 \pm 9$ \\
\hline Total resuspension & Cajarc & 15 & $640 \pm 115$ & $11 \pm 10$ & $24 \pm 14$ \\
\hline & Temple & 18 & $900 \pm 178$ & $20 \pm 14$ & $27 \pm 17$ \\
\hline
\end{tabular}

${ }^{a}$ Data from Audry et al., 2004b. 